\title{
İSLÂM HUKUKUNDA ÇOK EŞLİLİĞİ MEŞRU KILAN ŞARTLAR VE BUNA RUHSAT VEREN ÖZEL DURUMLAR
}

\author{
(D İbrahim YILMAZa
}

$\ddot{0 ̈ z}$

Çok eşlilik (poligami/teaddüd-i zevcât), yani erkeğin aynı anda birden fazla kadınla evlenmesi insanlık tarihinde bilinen ve uygulanan bir kurumdur. İslâm hukuku da belirli şartların ve gerekçelerin bulunması halinde çok eşlilik kurumunu bir ruhsat hükmü olarak kabul etmiş ve bunun sayısını dört ile sınırlandırmıştır. İslâm hukukunda çok eşlilik, mubah kılınmış olmakla birlikte her erkeğin keyfine göre kullanabileceği mutlak bir hak da değildir. Nitekim ilgili naslar incelendiğinde İslâm hukukunda çok eşliliğin mubah/meşru olabilmesinin; "eşler arasında adaleti gözetmek" ve "eşlerin nafakasını temin etmeye güç yetirebilmek" olmak üzere iki temel şarta bağlandığı görülmektedir. Diğer taraftan İslâm hukukunda çok eşliliğe ruhsat veren bireysel veya toplumsal bazı özel durumlar (şartlar/sebepler) üzerinde de durulmuştur.

İslam hukukunda çok eşlilik hakkının kullanılabilmesi ile ilgili doktrinde yer alan şartlar ve gerekçeler birlikte değerlendirildiğinde bu hakkın kullanılmasının şu üç temel şartın bulunmasına bağlandığını söylemek mümkündür; (1) Eşler arasında adalete riayet etmek, (2) Eşlerin nafakasını temin edebilecek yeterli mali güce/imkâna sahip olmak, (3) Ferdi veya toplumsal ihtiyaç veya zaruretin bulunması. Buna göre; İslâm hukukunda çok eşlilik, bireysel ve toplumsal bazı ihtiyaç ve zaruretler çerçevesinde karşılıklı rızaya dayalı olarak mubah kılınmış ahlakî ve hukukî bir kurum olmaktadır. Dolayısıyla erkekler, mevcut eşlerinin üzerine ikinci bir kadın ile evlenmek zorunda olmadıkları gibi, kadınların da ikinci bir eş olarak evli bir erkek ile evlenmeye hayır deme hakları vardır. Bu makalede, İslâm aile hukukunda çok eşliliğin meşruiyeti ve doktrinde çok eşlilik hakkını kullanmayı sınırlayan veya bu hakkı kullanmaya ruhsat veren bazı özel durumlar üzerinde durulacaktır.

Anahtar kelimeler: İslâm Hukuku, Çok Eşlilik, Ruhsat, Özel Durumlar

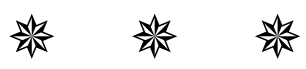

\footnotetext{
a Doç. Dr., Nevşehir Hacı Bektaş Üniversitesi İlahiyat Fakültesi, ibrh.yilmaz@hotmail.com
} 


\section{CONDITIONS THAT MAKE POLYGAMY LEGITIMATE AND SPECIAL CONDITIONS THAT ALLOW POLYGAMY IN ISLAMIC LAW}

Polygamy, the marriage of a man with more than one woman at the same time is a known and practiced institution in human history. Islamic law has accepted the institution of polygamy if it fulfills certain conditions and reasons as a substitute provision, and limited the number to four. Thus, relevant verses in the Qur'an (al-Nisa, 4/3, 129) and the Prophet's own practice (al-Ahzab, 33/50, 51, 59, alTahrim, 66 / 3-5) shows that it is legitimate for a man to marry more than one woman (up to four) at the same time in Islamic law.

Although polygamy is legally legitimate (mubah) in Islamic law it is not an absolute right that every man can arbitrarily use. Thus in Islamic law, the legitimacy of polygamy has been attributed to the presence of two basic conditions: the observance of justice and sustenance.

[The Extended Abstract is at the end of the article.]

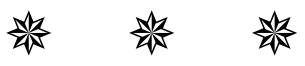

\section{Giriş}

Çok eşlilik/çok evlilik, erkeğin veya kadının aynı anda birden fazla eş ile evli olmasını ifade etmektedir. Erkeğin aynı anda birden fazla kadın ile evli olmasına "poligami"; kadının aynı anda birden fazla erkek ile evli olmasına ise "poliandri" denilmektedir. ${ }^{1}$ Poliandri pek uygulanan ve bilinen bir durum değildir. Poligami ise eski hukuk sistemlerinde, dini inançlarda ve toplumlarda bilinen ve uygulanan bir husustur. ${ }^{2} \mathrm{Bu}$ yüzden "çok eşlilik" veya "çok evlilik" denilince kastedilen genelde erkeğin aynı anda birden fazla kadınla evli olması (poligami) halidir. İslâm hukukunda, erkeğin aynı anda birden fazla kadınla evli olması hali (poligami), "çok eşlilik" anlamına gelen "teaddüd-i zevcât" tabiri ile ifade edilmektedir. ${ }^{3}$

Çok eșlilik, İslâm'ın ihdas ettiği bir kurum değildir. İslâm, daha önce Cahiliye Arap toplumunda (hukukunda) var olan ve sınırsız bir şekilde

${ }^{1}$ Kevser Kâmil Ali-Salim Öğüt, "Çok Evlilik”, Türkiye Diyanet Vakfı İslâm Ansiklopedisi (Ankara: TDV Yayınları, 1993), 8: 365.

${ }^{2}$ Sabri Şakir Ansay, Hukuk Tarihinde İslâm Hukuku, (İstanbul: Ajans Türk Matbaası, 1958), 195; Sadri Maksudi Arsal, Umumi Hukuk Tarihi, (İstanbul: İstanbul Matbaacılık, 1948), 131, 135; Musa Carullah, Kur'ân-ı Kerîm Âyetlerinin Nurları Huzurunda Hatun, Yay. Haz: Mehmet Görmez, (Ankara: Kitabiyat Yayınları,1999), 69-70; Mustafa es-Sibâî, el-Mer'e beyne'l-fikhi ve'l-kānûn, (Beyrut: el-Mektebetü'l-islâmî, 1999), 60-67; Bekir Topaloğlu, İslâmda Kadın, (İstanbul: Yağmur Yayınları, 1990), s. 96-98; Ali-Öğüt, "Çok Evlilik”, 8: 365366; Mustafa Öztürk, Cahiliyeden İslâmiyet'e Kadın, (Ankara: Ankara Okulu Yayınları, 2012), 39-42.

3 Kadının aynı anda birden fazla erkekle evli olması hali (poliandri), Arapça'da "teaddüdü'l-ezvâc" tabiri ile ifade edilmektedir. 
uygulanan bu kurumu tadil ederek kabul etmiştir. ${ }^{4}$ Nitekim İslâm hukukunda tek eşlilik teşvik edilmekle birlikte prensip olarak çok eşlilik de yasaklanmamış (en-Nisa, 4/3) ve erkeğin aynı anda birden fazla (en fazla dörde kadar) kadınla evlenebilmesine izin verilmiștir. ${ }^{5}$

Son dönemlerde özellikle Avrupa'nın da etkisi ile çok eşlilik kurumu üzerinde İslam'a yönelik eleştiriler hep varlığını devam ettirmiştir. ${ }^{6}$ Nitekim Tanzimat'tan (1839-1876)7 günümüze (kadar) çok eşlilik konusu İslâm aile hukukunda en çok tartışılan ${ }^{8}$ ve eleștirilen ${ }^{9}$ konulardan biri olmuştur. ${ }^{10}$

\footnotetext{
${ }^{4}$ Bkz. Adnan Demircan, "Câhiliye ve Hz. Peygamber Döneminde Çok Kadınla Evlilik”, İstem 1/2 (2003): 9, 16-18.

5 İslâm hukukunda çok eşlilik (teaddüd-i zevcât) hakkında geniş bilgi için bkz. Muhammed Hamdi Yazır Elmalılı, Hak Dini Kur'ân Dili, (İstanbul: Eser Neşriyat, 1979), 2: 1281-1291; Carullah, Hatun, 69-74; Muhammed Ebû Zehra, el-Ahvâlü'ş-șahsiyye, (Kâhire: Dâru'lfikri'i-Arabî, 1957), 89-96; Sibâî, el-Mer'e beyne'l-fikhi ve'l-kânûn, 60-99; Abdünnâsır Tevfîk Attâr, Teaddüdü'z-zevcât mine'n-nevâhî'd-dîniyye ve'l-ictimâiyye ve'l-kānûniyye, (Kahire: eș-Șirketü'l-Mısriyye li'tıbâati ve'n-neșr, 1972), 19-269; Ali-Öğüt, "Çok Evlilik", 8: 365-369; Topaloğlu, İslâmda Kadın, 98-124; Semra Ulaş, "İslâm'da Çok Kadınla Evlilik", İslâmî Araştırmalar 6/1 (1992): 52-63; Mehmet Özgü Aras, "İslâm’a Göre Çok Evlilik", Selçuk Üniversitesi İlahiyat Fakültesi Dergisi 24 (2007): 183-188.

${ }^{6}$ Ebû Zehra, el-Ahvâlü'ş-şahsiyye, 93; Ali-Öğüt, “Çok Evlilik”, 367-368.

7 Tanzimat, Osmanlı Padişahı Sultan Abdülmecid'in 1839 yılında Gülhane Hatt-ı Hümayunu'nu (Tanzimat Fermanı) yayımlaması ile başlayan modernleşme döneminin adıdır. Tanzimat, "düzenlemeler, reformlar" anlamlarına gelmektedir. Tanzimat Dönemi 1876 'da II. Abdülhamit'in tahta çıkması ve Meşrutiyet'in ilan edilmesi ile sona ermiş kabul edilmektedir. Tanzimat hakkında geniş bilgi için bkz. Ali Akyıldız, "Tanzimat", Türkiye Diyanet Vakfı Íslâm Ansiklopedisi (Ankara: TDV Yayınları, 2011), 40: 1-10.

${ }^{8}$ Bu konuda Osmanlı'da Mansurizâde Saîd (1864-1923) ile (Babanzâde) Ahmed Naim (1872-1934), arasındaki tartışmalara örnek olarak bkz. Mansurizâde Saîd, "Teaddüd-i Zevcât İslâmiyette Men Olunabilir", İslâm Mecmuası 1/8 (İstanbul 1330): 233-238; Ahmed Naim, "Teaddüd-i Zevcât İslâmiyet'te Men Olunabilir mi imiş?: Mansurizâde Saîd Beyefendi'ye", Sebilü'r-Reşad [Sırat-ı Müstakim], 11(12)/298 (15 Mayıs 1329/1330): 216221.

${ }^{9}$ Tarihçi İlber Ortaylı, tahmin edilenin aksine Osmanlı ailesinde çok eşlilik uygulamasının çok az olduğunu, hatta bu durumun tüm İslam ülkeleri için de geçerli olduğunu söylemektedir. Nitekim Ortaylı, Osmanlı ailesinin esas itibarıyla çok eşli olmadığını, çok eşlilik (polygamie) uygulamasının ise gayr-i ahlakî ve gayr-i hukukî bir durum olmadığını söylemektedir. Ortaylı'nın verdiği bilgiye göre, 1885-1906 yıları arasında Osmanlı'da çok eşlilik uygulamasının nüfusa dağılımı \% 2,51 ile \% 2, 61 arasında değişmektedir. (Bkz. İlber Ortaylı, Osmanlı Toplumunda Aile, (İstanbul: Timaș Yayınları, 2016), 123-126. İslâm ülkelerinde de çok eşlilik oranları benzer oranlardadır. Bkz. Ebû Zehra, el-Ahvâlü'şşahsiyye, 95-96; Vehbe ez-Zühaylî, el-Fıkhü'l-islâmî, (Dımeşk: Dâru'l-fikr, 1986), 7: 172 173. Asr-ı saadette de sahabe arasında çok eşliliğin gayet az olduğu ile ilgili bkz. Demircan, "Câhiliye ve Hz. Peygamber Döneminde Çok Kadınla Evlilik", 20-21.

${ }^{10}$ Osmanlı'da Tanzimat ile başlayan ve II. Meşrutiyet döneminde de devam eden çok eşlilik tartışmaları ile ilgili yapılan çalışmalar için bkz. İncegül, Sümeyye, Tanzimat'tan Günümüze Çok Evlilik Tartışmaları, (Yüksek Lisans Tezi, Erciyes Üniversitesi, Kayseri 2008); Akdaș, Hayrunnisa, II. Meșrutiyet Dönemi Fikir Akımlarının Teaddüd-i Zevcât Konusundaki Tartışmaları, Yüksek Lisans Tezi, (İstanbul: Marmara Üniversitesi, 2016).
} 
İslâm hukukunda belirli şartların ve gerekçelerin bulunması halinde meşru kılınan çok eşlilik, bireyin ve toplumun maslahatını korumaya yönelik ahlakî ve hukukî bir kurumdur. Bununla birlikte çok eşlilik, erkekler tarafından kötüye kullanılmaya ve istismar edilmeye de açık bir konudur. Bundan dolayıdır ki İslâm hukukçuları bir ihtiyaç ve/ya zaruret halinde ruhsat hükmü olarak meşru kılınan çok eşlilik hakkının kullanılabilmesi için -ilgili naslardan/ayetlerden hareketle- "eşler arasında adaleti gözetmek" ve "eşlerin nafakasını temin etmeye güç yetirebilmek" gibi bazı şartların bulunması gerektiğini belirtmişlerdir. Diğer taraftan aslen meşru olan çok eşlilik bireysel ve toplumsal bazı özel durumların (şartların/sebeplerin) bulunması halinde farklı hükümler de alabilmektedir.

Makalede İslâm aile hukukunda çok eşliliğin hükmü/meşruiyeti ve doktrinde çok eşliliği sınırlayan ve buna ruhsat veren bazı özel durumlar üzerinde durulacaktır.

\section{A. İslâm Hukukunda Çok Eşliliğin (Teaddüd-i Zevcât'ın)}

\section{Meşruiyeti}

İlgili nassın hükmünden hareketle İslâm hukukunda çok eşliliğin (teaddüd-i zevcât) meşruiyeti ile ilgili klasik doktrinde farklı bir görüş yoktur. Ancak son dönem İslam hukukçuları arasında bu konuda farklı görüşler ileri sürülmektedir. Bu yüzden İslâm hukukunda çok eşliliğin meşruiyeti ile ilgili görüşleri "klasik yaklaşım" ve "modern yaklaşım" şeklinde farklı başlıklar altında ele almak uygun olacaktır.

\section{1. Çok Eşliliğin Meşruiyeti ile İlgili Klasik Yaklaşım}

Kur'an'da yer alan ilgili naslar (en-Nisa, $4 / 3,139$ ) ve Hz. Peygamber'in bizzat kendi uygulaması (Bk. el-Ahzab, 33/50, 51, 59; et-Tahrim, 66/3-5) ${ }^{11}$, İslâm hukukunda erkeğin aynı anda birden fazla (en fazla dörde kadar) kadınla evlenmesinin mubah/meşru olduğunu göstermektedir. ${ }^{12}$ Nitekim İslâm hukukunda çok eşliliğin cevazı ile ilgili Kur'an-ı Kerim'de şöyle denilmektedir:

"Eğer, (velisi olduğunuz) yetim kızlar13 (ile evlenip onlar) hakkında

Ayrıca bkz. Fatma Aliye-Mahmud Esad, Çok Eşlilik (Teaddüd-i Zevcât), Haz: Firdevs Canbaz, (Ankara: Hece Yayınları, 2007), 13-103.

${ }^{11} \mathrm{~Hz}$. Peygamber'in dörtten fazla kadınla evli olması sadece ona has (hasâisü'n-Nebî) bir ruhsattır. Ümmet için teşrîi bir dayanak (mekîsün aleyh) olamaz. (Kurtubî, el-Câmi' li ahkâmi'l-Kur'ân, thk. Abdullah b. Abdulmuhsin et-Türkî, (Beyrut: Müessesetü'r-risâle, 2006), 6: 34; Abdülkerim Zeydan, el-Vecîz fî usîli'l-fikh, (Beyrut: Müessesetü'r-Risâle, 2011), 130; Muhammed el-Arûsî Abdülkadir, Ef âlü'r-rasûl ve delâletühü ale'l-ahkâm, (Cidde: Daru'l-müctemâ' li'n-neşr ve't-tevzî', 1991), 166-174.

12 Kurtubî, el-Câmi', VI, 24, 26, 33; Elmalılı, Hak Dini, 2: 1290; Sa'dî Ebû Ceyb, Mevsûatü'licmâ', fi'l-fikhı'l-islâmî, (Dımeșk: Dâru'l-fikr, 1984), 2: 1087.

${ }^{13} \mathrm{Bu}$ ayetten bir önceki ayet şöyledir: "Yetimlere mallarını verin. Temizi pis olanla (helâli haramla) değișmeyin. Onların mallarını kendi mallarınıza katıp yemeyin. Çünkü bu, büyük 
adaletsizlik etmekten korkarsanız, (onları değil), size helâl olan (başka) kadınlardan ikişer, üçer, dörder olmak üzere nikâhlayın. Ĕger (o kadınlar arasında da) adaletli davranmayacağınızdan korkarsanız, o takdirde bir tane alın veya sahip olduğunuz (cariyeler) ile yetinin. $\mathrm{Bu}$, adaletten ayrılmamanız için daha uygundur.( en-Nisa, 4/3)" 14

$\mathrm{Bu}$ ayetin ${ }^{15}$ sevk ediliş sebebi, bir diğer ifade ile teşri kılınma amacı, yetim kızlara adaletli davranılması ve erkeğin aynı anda birden fazla (en çok dörde kadar) kadınla evlenmesinin mubah olmasıdır. ${ }^{16}$ Ayet bu konuda nastır ${ }^{17}$, yani ayetin sevk ediliş sebeplerinden biri de erkeğin aynı anda birden fazla (en fazla dörde kadar) kadınla evlenmesinin mubah olduğunu ifade etmektir. ${ }^{18}$ Diğer taraftan Hz. Peygamber'in, beş kadınla evli olarak

bir günahtır." (Nisa, 4/2) Sebeb-i nüzullerden anlaşıldığına göre bu ayetler, genel olarak yetimlerin (yetim kızların) șahsî ve malî haklarının korunması ile ilgilidir. (Bkz. Elmalılı, Hak Dini, 2: 1282-1287).

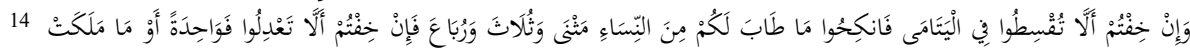

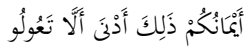

${ }^{15} \mathrm{Bu}$ ayetlerin sebeb-i nüzulü hakkında nakledilen rivayetler için bkz. Kurtubî, el-Câmi', 6: 23-24; Elmalılı, Hak Dini, 2: 1282-1287.

16 İbn Rüșd, Bidâyetü'l-müctehid ve nihâyetü'l-muktesid, (Beyrut/Kahire: Dâru'l-ceylMektebetü'l-külliyeti'l-ezheriyye, 2004), 2: 64; Merğînânî, el-Hidâye, (İstanbul: Kahraman Yayınları, 1986), 2: 194; İbn Kudâme, el-Muğnî, thk. Abdullah b. Abdülmuhsin et-TürkîAbdülfettah Muhammed el-Hulüv, (Riyad: Dâru Âlemi'l-kütüb, 1997), 9: 371-472; Şirbînî, Muğni'l-muhtâc, (Beyrut: Dâru'l-ma'rife, 1997), 3: 241. Ayrıca bkz. Abdülkerim Zeydan, elMufassal fí ahkâmi'l-mer'e ve'l-beyti'l-müslim fi'ş-şerîati'l-islâmiyye, (Beyrut: Müessesetü'rrisâle, 1993), 6: 286.

17 Fıkıh usulünde, lafız (ayet) belirli bir manayı/hükmü açılamak üzere sevkedilmișse bu lafza, fikıh usulü terimi olarak "nass" denir. Nass olan lafız, sevkedildiği manaya açıkça delalet eder. Sevkediliș amacı olmamakla birlikte, kendisi ișitilince manası hemen açıkça anlașılan lafza ise fikıh usulü terimi olarak "zâhir" denir. Bkz. Debûsî, Takvîmü'l-edille fî usûli'l-fikh, thk. Şeyh Halil Muhyiddin el-Meys, (Beyrut: Dâru'l-kütübi'l-ilmiyye, 2007), 116; Zekiyyüddin Şaban, İslâm Hukuk İlminin Esasları (Usûlü'l-fikıh), trc. İbrahim Kâfi Dönmez, (Ankara: Diyanet Vakfı Yayınları, 2015), 369, 371; Fahrettin Atar, Fıkıh Usûlü, (İstanbul: MÜIFV Yayınları, 1996), 209-210.

18 Debûsî, Takvîmü'l-edille, 116; Şaban, Usûlü'l-fikh, 369-370, 393-394; H. Yunus Apaydın, İslâm Hukuk Usulü, (Ankara: Bilay, 2017), 232. Ayrıca bkz. Cessâs, Ahkâmü'lKuur'an, thk. Muhammed Sadık Kamhâvî, (Beyrut: Dâru ihyâi't-türâsi'l-Arabî, 1985), 2: 341-342; Kurtubî, el-Câmi', VI, 26, 33; Elmalılı, Hak Dini, 2: 1290.

Burada verilen kaynaklarda, Nisa, 4/3 ayetinin, sevk ediliş sebeplerinden birinin de; erkeğin aynı anda birden fazla (en fazla dörde kadar) kadınla evlenmesinin mubahlığına delalet etmesi olup ayetin bu yönü ile "nass" olduğu ifade edilmiştir. Bazı kaynaklarda ise ayetin asıl sevk ediliş sebebinin yetim kızlara adalet ile muamele edilmesi ve onların haklarının korunması olup ayetin bu yönü ile "nass" olduğu, ayetin ibaresi (siğası) ile doğrudan erkeğin aynı anda birden fazla (en fazla dörde kadar) kadınla evlenmesine delalet ettiği, bu yönü ile ise ayetin "zahir" olduğu ifade edilmiștir. (Bkz. Atar, Fıkıh Usûlü, 209-210.) Ancak, klasik fikıh doktrini açısından Nisa, 4/3. ayetin teaddüd-i zevcât konusunda "nass" veya "zahir" olması İslâm hukukunda çok eşliliğin hükmünü veya 
İslâmiyet'i kabul eden Nevfel b. Muâviye'ye bunlardan birisini bırakmasını ${ }^{19}$; sekiz kadınla evli olan ${ }^{20}$ Kays b. Hâris ile on kadınla evli olan ${ }^{21}$ Gaylân b. Seleme'ye de dörtten fazla olan hanımlarını boşamalarını emretmesi, İslâm hukukunda çok eşliliğin mubah ve dörtle sınırlı olduğunu göstermektedir. Konuyla ilgili yukarıdaki nasları ve Hz. Peygamber'in bizzat kendi uygulamasını esas alan İslâm hukukçuları da, İslâm hukukunda çok eşliliğin mubah/caiz olduğu hususunda ittifak/icma etmişlerdir. ${ }^{22}$

Yukarıdaki açıklamalardan da anlaşılacağı üzere İslâm hukukunda çok eşlilik, evlenme ehliyetine sahip olan her erkeğin uygulaması gereken bir emir veya (zorunlu) aslî bir hüküm (azimet) değildir. Aksine belirli şartların ve gerekçelerin bulunması halinde meşru kılınmıș istisnâî bir hükümdür. ${ }^{23}$ Nitekim İslâm hukukunda çok eşliliğin bir emir değil de ihtiyaç ve zaruret halinde izin verilmiş bir ruhsat hükmü olmasından hareketle Ahmed Hamdi Akseki (1887-1951) şu tespitte bulunmaktadır:

“Teaddüd-i zevcât islâmiyette emredilmiş (me'mûrun bih) değil, belki izin verilmiştir (me'zûnun fîh); Frenklerin, Frenk mukallitlerinin, "din"den habersiz cahillerin, hevâperestlerin anladıkları gibi Kur'ân mutlak olarak teaddüd-i zevcât ile âmir değildir. Kur'ân'da mutlak olarak teaddüd-i zevcât ile emir değil, belki bundan -mutlak birçok evlilikten- açık bir şekilde nehiy vardır." 24

Şu halde; İslâm hukukunda çok eşlilik, belirli şartlar çerçevesinde karşılıklı rızaya dayalı olarak mubah/meşru kılınmış ahlakî ve hukukî bir kurum olmaktadır. Dolayısıyla erkekler, mevcut eşlerinin üzerine ikinci bir kadın ile evlenmek zorunda olmadıkları gibi, kadınların da ikinci bir eş olarak

meșruiyet gerekçesini değiştirmemektedir. Çünkü her iki yaklaşıma göre de ayet ibaresiyle doğrudan erkeğin aynı anda birden fazla (en fazla dörde kadar) kadınla evlenmesinin mubah olduğuna delalet etmektedir.

${ }^{19}$ Beyhakî, es-Sünenü'l-Kübrâ, 7: 184.

20 İbn Mâce, "Nikāh", 40.

${ }^{21}$ Tirmîzî, "Nikāh", 33

${ }^{22}$ Ebû Ceyb, Mevsûatü'l-icmâ', 2: 1087.

${ }^{23}$ Reșid Rıza, Tefsîrü'l-Menâr, (Mısır: Matbaatü'l-Menâr, 1328 h), 4: 348-349; Muhammed Tahir b. Âșûr, et-Tahrîr ve't-tenvîr, (Tunus: Dâru'-Tûnisiyye, 1984), 4: 226; Elmalılı, Hak Dini, 2: 1290; Carullah, Hatun, 70, 74; Ahmed Hamdi Akseki, "İslamiyet ve Teaddüd-i Zevcât", Osmanlıdan Cumhuriyete İslam Düşüncesinde Arayışlar, (İstanbul 1999): 272, 278, 295, 305; Öme Nasuhi Bilmen, Hukuk-ı İslâmiyye ve Istılahât-ı Fıkhiyye Kamusu, (İstanbul: Bilmen Yayınları, 1985), 2: 113; Mustaf Ahmed ez-Zerkā, el-Medhalü'l-fikhîl'-âmm/elFıkhu'l-İslâmî fi sevbihi'l-cedîd, (Dimeşk: Dâru'l-Fikr, 1968), 1: 36; Hayreddin Karaman, İslâm'da Kadın ve Aile, (İstanbul: Ensar Neşriyat, 1994), 393-394; Ali-Ögüt, "Çok Evlilik", 8: 366; Saffet Köse, "Aile Hukuku”, İslâm Hukuku El Kitabı, edt. Talip Türcan, (Ankara: Grafiker Yayınları, 2012): 472; H. Yunus Apaydın, "Nikâh Akdinin Mahiyeti ve İmam Nikâhı Uygulaması", Erciyes Ünv. Sosyal Bilimler Enst. Dergisi 9 (2000): 379.

${ }^{24}$ Akseki, "İslâmiyet ve Teaddüd-i Zevcât", 297. 
evli bir erkek ile evlenmeye hayır deme hakları vardır. ${ }^{25}$ Bu konuda dikkat çekilmesi gereken önemli bir husus da İslâm hukukunda çok eşlilikte asıl olan mubahlık olmakla birlikte, -aşağıda zikredilen- bireysel veya toplumsal ihtiyaç ve zaruretlerin bulunduğu bazı durumlarda mendup veya vacip de olabilmektedir. ${ }^{26}$

\section{2. Çok Eşliliğin Meşruiyeti ile İlgili Modern Yaklaşım}

Konuyla ilgili ayetin (Nisa, 4/3), İslâm hukukunda çok eşliliğ̈in mubah olduğuna sarih bir şekilde delalet ettiği hususunda klasik fikıh doktrininde ittifak vardır. Ancak son dönem İslâm hukukçularından bazıları çok eşliliğin meşruiyetine dayanak teşkil eden bu ayetin sevk ediliş amacından hareketle bu konuda farklı görüşler ileri sürmektedirler.

Örneğin Musa Carullah Bigiyef (1875-1949)27, Nisa, 4/2-3. ayetlerde

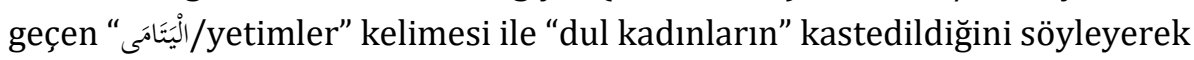
Nisa, 4/3. ayette çok eşliliğin mubah olmasına doğrudan delil olabilecek/delalet eden herhangi bir ibarenin bulunmadığını söylemektedir. Zira ona göre "Ayette 'الْيَّامَى / yetimler' ile kastedilen kocası/kimsesiz dul kadınlardır. Eğer hatun dul olarak âciz kalır, hukuku, ihtiyaçları ve saygınlığının temin edilememe tehlikesi bulunursa, bunları temin etmek farz-ı kifâye olur. Hitap ümmetin umumuna yöneliktir. Ümmetten birisi bunu yerine getirirse yeterli olur. Ayette belâğat ve mübâlağa yoluyla bunları temin etmek için alınacak nihai tedbirlere misal olarak çok eşliliğe değinilmiştir. Ayetin asıl anlamı: "Dul kalan kadınlardan iki, üç ve dört hatun almak suretiyle de olsa, çaresiz kalmış dul kadınların hak ve ihtiyaçlarını temin ediniz" demektir." 28

\footnotetext{
${ }^{25}$ Bilmen, Hukuk-ı İslâmiyye ve Istılahât-ı Fıkhiyye Kamusu, 2: 114.

${ }^{26}$ Carullah, Hatun, 74; Elmalılı, Hak Dini, 2: 1290; Ebû Zehra, el-Ahvâlü'ş-șahsiyye, 95.

${ }^{27}$ Aslen Güney Rusya'da Penza ilinin Çembar ilçesine bağlı Kikino köyünden olup Kazan'a giderek Kül Buyı (Göl Boyu) Medresesi'nde, daha sonra Mâverâünnehir'e geçip Buhara medreselerinde eğitim gören Musa Carullah İslâm coğrafyasının değișik illerine seyahat etmiş ve birçok ilmi toplantılara katılmıştır. 1904 yılında Rusya'da Petersburg Üniversitesi Hukuk Fakültesi'ne misafir öğrenci olarak devam eden Carullah İslâm hukuku çalıșmalarına ve İslâm Hukukunda kadının konumuna ayrı bir önem vermiștir. Tatar âlimi olan Musa Carullah Bigiyef'in (1875-1949) hayatı hakkında geniş bilgi için bkz. Ahmet Kanlıdere, "Musa Carullah", Türkiye Diyanet Vakfi İslâm Ansiklopedisi (Ankara: TDV Yayınları, 2002), 26: 214-216.

${ }^{28}$ Carullah, Hatun, 70.

Elmalılı Muhammed Hamdi Yazır da (ö. 1942) lügat noktai nazarından kocasız kalan dul kadınlara da "yetim" denildiğini, dolayısıyla ayette ale'l-umûm her iki manada, yani babası ölen kız çocukları ve kocasız kalan dul kadınlar hakkında adaletli ve hakkaniyetli davranılması gerektiğini söylemektedir. (Elmalılı, Hak Dini, II, 1280, 1281, 1287.) Elmalılı bu konuyu şöyle bağlamaktadır: "Sebeb-i nüzul gerek münhasıran sığârı eytâm olsun ve gerekse mutlak menkûhalarla da alakadar bulunsun her halde âyetin ale'l-1tlâk adalet-i nisvân hikmet ve gayesiyle alâkadar bulunduğu dahi aşikârdır. Binaenaleyh sebebin hususi olması, mefhum ve hükmün hususiyetini iktizâ etmeyeceğinden "Şayet yetimler
} 
Musa Carullah (1875-1949), konuyla ilgili delil ve gerekçelerini zikrettikten sonra konuyu şöyle bağlamaktadır: "Netice itibarıla, Kur'an-ı Kerim'de çok eşliliğin cevazı hususunda her hangi bir ibare yoktur. Sadece kimsesiz kadınların özel durumları münasebetiyle bir ișaret vardır. Kaldı ki bu işaret de mutlak değil, takdiridir. Yani çaresiz dul kadınların ihtiyaçlarını teminat altına almak için nihai bir tedbir takdiriyle işaret edilmiştir." 29

Yukarıdaki ifadelerinden anlaşılacağı üzere Musa Carullah'a göre Nisa, 4/2-3. ayetler, kocasız dul kadınların haklarını koruma gayesiyle nazil olmuştur. Dolayısıyla Nisa, 4/3. ayetin ibaresinden çok eşliliğin mubah olduğu anlamı çıkartılamaz. Bu ayette dolaylı olarak zaruret halinde çok eşliliğin mubah/caiz olabileceğine işaret edilmiștir. Kısaca Musa Carullah'a göre bu ayet bir azimet hükmü olarak değil, zaruret halinde bir ruhsat hükmü olarak çok eşliliğin mubah olduğuna işaret etmektedir. ${ }^{30}$

Son dönem İslâm hukuku araştırmacılarından Abdünnâsır Tevfîk Attâr ise konuyla ilgili Nisa, 4/3. ayetin sevk ediliş amacının çok eşliliğin mubahlığı hükmünü teşri kılmak olmadığını, nitekim Kur'an'da çok eşliliğin doğrudan mubah olduğunu söyleyen sarih bir ayetin bulunmadığını söylemektedir. Attâr'a göre çok eşliliği mubah kılan ayette kullanılan üslûb da Kur'an'da yer alan ibaha üslûpları ile tam olarak örtüşmemektedir. Zira Kur'an'da ibaha üslupları genelde "bunu yapmanızda sakınca yoktur", "bu size helal kılındı" şeklinde gelirken çok eşlilikte mubah kılma üslubu "emir kipi" ile gelmiştir. Bu da göstermektedir ki, çok eşliliğ̈in mubah olmasına delil olarak gösterilen ayetin asıl amacı çok eşliliği mubah kılmanın dışında başka bir şeydir ${ }^{31} \mathrm{ki}$ bu da yetim kızlara haksızlık ve zulüm yapılmamasıdır. ${ }^{32}$ Dolayısıyla İslâm hukukunda Nisa, 4/3 ayeti, bi'l-asl değil bi't-tebea çok eşliliğin cevazına delil olmaktadır. ${ }^{33}$

Günümüz İslam hukukçularından akademiysen Prof. Dr. Mustafa Ylldırım da, Nisa, 4/3. ayetin çok eşliliğin mubah olduğunu teşri kılmak amacıyla değil, yetimlerin haklarının korunması amacıyla teşri kılındığını,

hakkında adaletli davranmaktan endişe ederseniz" cümlesindeki "yetâmâ" lafzı velev delaleten olsun dul kadınlara şamil bir mefhum-ı âmmi ile mülâhaza edilirse ayetin hükmü ve hikmeti daha ziyade bir vuzuh ile mutalaa olunabilecektir." (Elmalılı, Hak Dini, 2: 1287.) Ancak şunu ifade etmekte fayda var; Elmalılı her ne kadar "yetâmâ" lafzının babası ölmüș küçük kızlar ve kocasız kalmıș dul kadınlar manasına geldiğini ifade etse de, "âyetin ale'l-1tlâk adalet-i nisvân hikmet ve gayesiyle alâkadar bulunduğu dahi așikârdır" demekte ve ayetin mutlak olarak İslâm hukukunda çok eşliliğin meşruiyetine delil olduğunu da ifade etmektedir. (Elmalılı, Hak Dini, 2: 1290.)

${ }^{29}$ Carullah, Hatun, 72-73.

${ }^{30}$ Carullah, Hatun, 70, 74-77. Bu konuda ayrıca bkz. Akseki, "İslâmiyet ve Teaddüd-i Zevcât", 272, 278, 295, 305.

${ }^{31}$ Attâr, Teaddüdü'z-zevcât, 119-120.

${ }^{32}$ Attâr, Teaddüdü'z-zevcât, 136.

${ }^{33}$ Akseki, "İslâmiyet ve Teaddüd-i Zevcât", 298, 301. 
dolayısıyla bu ayetten İslâm hukukunda çok eşliliğin mubah/meşru kılındığı ve bunun sayısının dörtle sinırlı olduğu şeklinde bir hükmün çıkarılamayacağını söylemektedir. ${ }^{34}$ Ayrıca Yıldırım'a göre Nisa, 4/3. ayet, çok eşliliği dörtle sınırlamamaktadır. Nitekim Hz. Peygamber'in bizzat kendisi, aynı anda dörtten fazla kadınla evlenmiştir. Hz. Peygamber'in bu uygulamasının kendisine mahsus (hasâisü'n-Nebî) bir hüküm olduğuna dair ciddi bir delil de yoktur. ${ }^{35}$ Yıldırım'a göre Nisa, 4/3 ayeti çok eşlilik ile ilgili hukuki bir düzenleme de getirmiş değildir. Kur'an bu konuyu gündemine almamıştır. Bu ayetten çok eşlilik ile ilgili hukuki bir düzenleme çıkarmak ayetin sevk ediliş amacı açsından mümkün değildir. ${ }^{36}$ Bununla birlikte Kur'an çok eşliliği yasaklamış da değildir. Zira Nisa, 4/3, 129. ayetlerin zahiri bu anlayışa izin vermemektedir. Diğer taraftan İslâm'da evlilik mubah bir fiildir. Çok eşliliğin sayısını ise toplumsal ihtiyaçlar ve zaruretler belirler. Nitekim kadın nüfusunun erkek nüfusundan çok fazla olduğu Malezya'da erkeğin aynı anda yedi, on kadınla evlenmesine fetva verildiği dönemler olmuştur. ${ }^{37}$

İslâm hukukunda çok eşliliğin (teaddüd-i zevcât) meşruiyeti ve mubah olması ile ilgili modern yaklaşımın ileri sürdügü gerekçelere ve görüşlere genel olarak katılıyoruz. Ancak lafız, sebeb-i nüzul ve hikmet-i teşri bağlamında, Nisa, 4/3. ayetinin doğrudan İslâm hukukunda çok eşliliğin mubah olduğuna delil olmadığı şeklindeki görüsslere ve Musa Carullah'ın bu ayete vermiş olduğu; "Ayetin asıl anlamı: "Dul kalan kadınlardan iki, üç ve dört hatun almak suretiyle de olsa, çaresiz kalmış dul kadınların hak ve ihtiyaçlarını temin ediniz" demektir" 38 şeklindeki yorumlarını isabetli bulmuyoruz.

Şöyle ki, yukarıda da zikrettiğimiz gibi usulcülere/İslâm hukukçularına göre, Nisa, 4/3. ayeti, İslâm hukukunda çok eşliliğin mubah olduğu hususunda "nass'tır" 39 ve ibaresiyle/sîğasıyla doğrudan çok eşliliğin

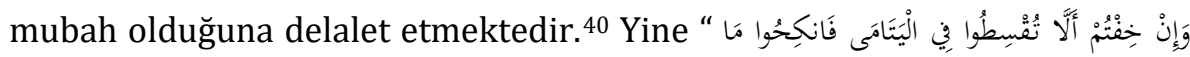

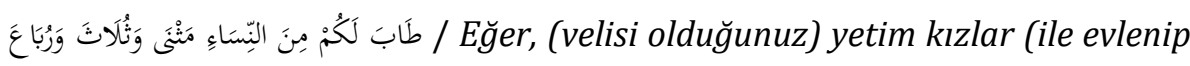

\footnotetext{
${ }^{34}$ Mustafa Yıldırım, "Nisa Suresi 3. Ayet Bağlamında Çok Eşlilik Meselesi”, Dinlerde Nikâh Milletlerarası Tartışmalı İlmi Toplantı (İzmir 06-08 Nisan 2012), (İstanbul: 2012): $537-$ 539.

${ }^{35}$ Yıldırım, "Nisa Suresi 3. Ayet Bağlamında Çok Eşlilik Meselesi", 539-540.

${ }^{36}$ Yıldırım, "Nisa Suresi 3. Ayet Bağlamında Çok Eşlilik Meselesi", 542-543.

${ }^{37}$ Yıldırım, "Nisa Suresi 3. Ayet Bağlamında Çok Eşlilik Meselesi", 543-544.

${ }^{38}$ Carullah, Hatun, 70.

39 Fikı usulünde ayetin metninin/ibaresinin "nass" ve/ya "zahir" olması ile neyin kastedildiği hakkındaki açıklama yukarıdaki dipnotlarda geçmiști. Konuyla ilgili ayrıca bkz. Debûsî, Takvîmü'l-edille, 116; Șaban, Usûlü'l-fıkh, 369, 371; Atar, Fıkıh Usûlü, 209-210. 40 Debûsî, Takvîmü'l-edille, 116; Şaban, Usûlü'l-fikh, 369-370, 393-394; Apaydın, İslâm Hukuk Usulü, 232. Ayrıca bkz. Elmalılı, Hak Dini, 2: 1290.
} 
onlar) hakkında adaletsizlik etmekten korkarsanız, (onları değil), size helâl olan (başka) kadınlardan ikişer, üçer, dörder olmak üzere nikâhlayın" (enNisa, 4/3) ayetinde manayı "dul kadınlara" tahsis edecek sarih bir delil

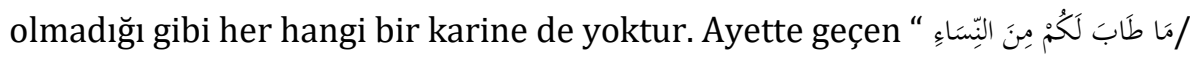
size helâl olan (başka) kadınlardan" ibaresi mutlaktır ve umum ifade etmektedir. Dolayısıyla ayetin hükmü içerisine yetim kızlar, dul kadınlar, daha önce evlilik yapmamış kızlar/kadınlar, kısaca evlenilmesinde șer'an bir mani bulunmayan tüm kadınlar girmektedir. ${ }^{41}$

Buna göre ayetin nüzul sebebinin yetimler veya dul kadınlar olması ya da ayetin yetim ve dul kadınların haklarının korunması ve gözetilmesi gayesi ile nazil olması ayetin umum ifade etmediği anlamına gelmez. Diğer taraftan ayetin hükmünü yetim kızlara veya dul kadınlara hasretmek, ayetin umum anlamın (hükmün) nüzul sebebi veya gayesi ile tahsis edilmesi anlamına gelmektedir. Âmm lafzın (umum ifade eden nassın) nüzul sebebi veya mütekellimin (Şâri'in) garazı/maksadı ile tahsis edilmesi ise Hanefilere göre fasid istidlaldir, Şafiilere göre ise mümkündür. ${ }^{2}$ Ancak fıkıh usulü kitaplarında "âmmın nüzul sebebi veya gayesi ile tahsis edilmesi" konusuna verilen tartışmalı örnekler içerisinde Nisa, $4 / 3$. ayetine yer verilmemektedir. Bu da Nisa, 4/3. ayetin ifade ettiği çok eşlilik (teaddüd-i zevcât) hükmünün umum ifade ettiği hususunda bir ihtilafın olmadığını göstermektedir. Nitekim yukarıda da ifade ettiğimiz üzere İslâm hukukçuları, -dul, yetim, vs. şeklinde herhangi bir ayırım yapmaksızın- çok eşliliğin tüm kadınlar için mubah olduğu hususunda ittifak/icma etmişlerdir. ${ }^{43}$

Diğer taraftan nasların ibaresinin/lafzının hükme delaleti hususunda; / Sebebin hususiliğine değil lafzıı umumiliğine itibar edilir" 44 kuralı fıkıh usulünde temel bir ilke olarak kabul edilmiştir. Dolayısıyla İslâm hukukunda çek eşliliğin meşruiyetine dayanak teşkil eden ayet (en-Nisa, 4/3) umum ifade etmekte olup dul kadınlara tahsis edilmesi isabetli değildir. ${ }^{45}$ Dahası -savaş, doğal afet vs. gibi- değişik sebeplerden dolayı toplumda hiç evlilik yapmayan kadınların sayısı, evlenip dul kalan kadınların sayısından daha fazla olabilir. Böyle bir durumda çok eşliliğin cevazını dul kadınlarla sınırlamak, çok eşliliğin teşri kılınmasındaki hikmet ve maslahatı gerçekleştirme hususunda yetersiz kalacaktır.

Sonuç olarak İslâm hukukunda çok eşliliğin meşruiyetine dayanak

${ }^{41}$ Cessâs, Ahkâmü'l-Kur'an, 2: 342; Kurtubî, el-Câmi', 6: 29; Attâr, Teaddüdü'z-zevcât, 133, 135.

42 Bkz. Atar, Fıkıh Usûlü, 198-199.

${ }^{43}$ Cessâs, Ahkâmü'l-Kur'an, 2: 342; Kurtubî, el-Câmi', 6: 29; Ebû Ceyb, Mevsûatü'l-icmâ', 2: 1087; Attâr, Teaddüdü'z-zevcât, 133, 135.

${ }^{44}$ Bkz. Debûsî, Takvîmü'l-edille, 116; Șaban, Usûlü'l-fıkıh, 358.

${ }^{45}$ Bkz. Elmalılı, Hak Dini, 2: 1281, 1287, 1290. 
teşkil eden Nisa, 4/3 ayetinin sevk ediliş amacından hareketle son dönem İslam hukukçuları arasında farklı yorumlar yapılması sonucu etkilememektedir. Nitekim konuyla ilgili tüm yorumlar, Nisa, 4/3. ayetinin doğrudan veya dolaylı olarak İslâm hukukunda çok eşliliğin mubah olduğu ortak paydasında birleşmektedir. ${ }^{46}$

\section{B. Doktrinde Çok Eşliliği Meşru Kılan Şartlar ve Buna Ruhsat Veren Özel Durumlar}

İslâm hukukunda çok eşlilik mubah/meşru olmakla birlikte bu hakkın kullanılması bazı özel şartların bulunmasına veya buna ruhsat veren bazı özel durumların bulunması şartına bağlanmıştır. Așağıda kısaca İslam hukukunda çok eşliliği sınırlayan veya buna ruhsat veren/bunu gerektiren bu özel durumlar üzerinde durulacaktır.

\section{1. Çok Eşliliği Meşru Kılan Şartlar}

İslâm hukukunda çok eşlilik, bir ruhsat hükmü olarak mubah kılınmış olmakla birlikte her erkeğin keyfine göre kullanabileceği mutlak bir hak da değildir. Nitekim ilgili naslar incelendiğinde İslâm hukukunda çok eşliliğin mubah/meşru olabilmesinin; "eşler arasında adaleti gözetmek" (en-Nisa, $4 / 3,129$ ) ve "eşlerin nafakasını temin etmeye güç yetirebilmek" (en-Nisa, $4 / 3$, 34; en-Nur, 24/33) ${ }^{47}$ olmak üzere iki temel şarta bağlandı̆̆ görülmektedir. ${ }^{48}$ Aşağıda kısaca bu şartlar üzerinde durulacaktır.

\section{a. Adalet: Eşler Arasında Maddi Eşitliğin Sağlanması Şartı}

İlgili ayetler (en-Nisa, 4/3, 129) incelendiğinde İslâm hukukunda çok eşlilik hakkının kullanılmasının meşruiyeti ile ilgili Kur'an'da doğrudan ve açık olarak zikredilen tek şartın, "eşler arasında adaletin gözetilmesi şartı" olduğu görülmektedir. ${ }^{49}$

Nitekim ilgili ayette kocanın eşleri arasında maddi adaleti gözetmesi gerektiği ile ilgili şöyle denilmektedir:

\footnotetext{
${ }^{46}$ Bkz. Yıldırım, "Nisa Suresi 3. Ayet Bağlamında Çok Eşlilik Meselesi", 543-544

${ }^{47}$ Ayrıca bkz. Buhârî, "Savm", 10; Nikâh, 2,3; Müslim, "Nikāh", 1,3; Ebû Dâvûd, "Nikāh",1; Tirmizî, "Nikāh", 1; Nesâî, "Nikāh", 3, "Sıyâm", 43; İbn Mâce, "Nikāh", 1.

${ }^{48}$ Ebû Zehra, el-Ahvâlü'ş-şahsiyye, 90-91; Muhammed Ebû Zehra, el-Muhâdarât fí akdi'zzevâc ve eserih, (Kahire: Daru'l-fikri'l-arabî, 1971), 133-134; Muhammed Ebû Zehra, Tanzîmü'l-üsra ve tanzîmü'n-nesl, (Kahire: Daru'l-fikri'l-arabî, 1976), 66; Muhammed Mustafa Şelebî, Ahkāmü'l-üsre fi'l-íslâm, (Beyrut: Dârü'n-Nehdati'l-Arabiyye, 1977), 235; Sibâî, el-Mer'e beyne'l-fikhi ve'l-kânûn, 80, 92-94; Zeydan, el-Mufassal fí ahkâmi'l-mer'e, 6: 287-289; Zühaylî, el-Fıkhü'l-islâmî, 7: 168. Ayrıca bkz. Cessâs, Ahkâmü'l-Kur'an, 2: 346, 348.

49 Bkz. Reşid Rıza, Tefsîrü'l-Menâr,4: 348-349; Akseki, "İslâmiyet ve Teaddüd-i Zevcât", 294, 303-313. Ayrica bkz. Abdullah Durmuş, “Ahmed Hamdi Akseki'nin Birden Fazla Evlilik (Çok Eşlilik) Konusundaki Yaklaşımı”, İstanbul Üniversitesi İlahiyat Fakültesi Dergisi 32, (2015): 268-273.
} 


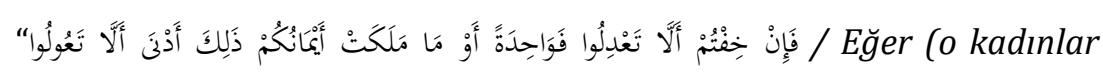
arasında da) adaletli davranmayacağınızdan korkarsanız, o takdirde bir tane alın veya sahip olduğunuz (cariyeler) ile yetinin. Bu, adaletten ayrılmamanız için daha uygundur" (en-Nisa, 4/3)

Kocanın eşleri arasında adaleti gözetmesi gerektiği ile ilgili $\mathrm{Hz}$. Peygamber ise şöyle buyurmaktadır:

"Kimin iki hanımı olur da bunlardan birine farklı ilgi gösterirse kıyamet gününde bir tarafi felçli olarak haşredilecektir." 50

İslâmî literatürde "adalet" kavramının ahlak, fikıh/hukuk ve hadis ilim dallarına göre farklı tanımları yapılmıştır. ${ }^{51}$ Konumuzla ilgili söz konusu edilen adalet ise ahlakî ve hukukî anlamdaki adalettir. Ahlaki anlamda adalet, "ferdi ve sosyal yapıda dirlik ve düzenliği, hakkaniyet ve eşitlik esaslarına uygun şekilde davranmayı sağlayan ahlaki erdem"52 olarak tanımlanmaktadır. Ahlaki anlamı ile yakın ilişkisi bulunan hukukî anlamda adalet ise "taraflar veya kişiler arasında dengeyi sağlamak, herkese hakkını vermek" 53 anlamına gelmektedir. Adaletin karşıtı ise, "zulüm", yani haksızlık ve hakka tecavüzdür. ${ }^{54}$

Koca, eşleri arasında adaletli gözetmekle yükümlüdür. ${ }^{55}$ Dolayısıyla erkeğin aynı anda birden fazla kadınla evlenmesine şer'an cevaz verilmesinde "adalet" şartının bulunup bulunmaması merkezi bir öneme sahiptir. Nitekim İslâm hukukçuları, ilgili ayetin (Nisa, 4/3) doğrudan ve sarih bir şekilde çok eşliliğin cevazını, "eşler arasında adaleti gözetme" şartına bağladığı konusunda ittifak etmişlerdir. ${ }^{56}$ Ayette "adalet" kelimesi mutlak olarak zikredilmekle birlikte57 İslâm hukukçularının büyük

\footnotetext{
${ }^{50}$ Ahmed b. Hanbel, Müsned, 2: 295, 347, 471; Ebû Dâvûd, "Nikāh", 38; Tirmîzî, "Nikāh", 42.

51 Çă̆rıcı, Mustafa (Ahlak), Karaman, Hayreddin (Fıkıh), Aydınlı, Abdullah (Hadis) "Adalet" Türkiye Diyanet Vakfı Íslâm Ansiklopedisi (Ankara: TDV Yayınları, 1988), 1: 341344.

52 Mustafa Çağrıcı, "Adalet” Türkiye Diyanet Vakfı İslâm Ansiklopedisi (Ankara: TDV Yayınları, 1988), 1: 341; Mehmet Erdoğan, "Adalet" mad., Flkıh ve Hukuk Terimleri Sözlüğü, (İstanbul: Rağbet Yayınları, 1998), 3.

${ }^{53}$ Hayreddin Karaman, (Flkıh), "Adalet" Türkiye Diyanet Vakfı İslâm Ansiklopedisi (Ankara: TDV Yayınları, 1988), 1: 343.

${ }^{54}$ Erdoğan, "Adalet" 3.

${ }^{55}$ Kurtubî, el-Câmi', 6: 37. Ayrıca bkz. Osmanlı Hukuk-ı Aile Kararnamesi, Yay. Haz. Orhan Çeker, (Konya: Mehir Vakfı Yayınları, 2012), 39 (md. 74); Ali-Öğ̈̈t, “Çok Evlilik”, 8: 366.

${ }^{56}$ Kurtubî, el-Câmi', 6: 37; Elmalılı, Hak Dini, 2: 1281-1282; Karaman, İslâm'da Kadın ve Aile, 393; Zeydan, el-Mufassal fî ahkâmi'l-mer'e, 6: 286; Zühaylî, el-Fıkhü'l-islâmî, 7: 168.

57 Kocanın eşleri arasında gözetmesi gereken biri "maddi adalet", diğeri ise "manevi adalet", olmak üzere iki türlü adaletten söz edilebilir. Maddi adalet ile kastedilen, nafaka, vs. gibi irade ve ihtiyarına bağlı olan durumlarda kocanın eşleri arasında adaleti gözetmesidir. Manevi adalet ile kastedilen ise, sevgi ve kalbin meyletmesi gibi irade ve
} 
çoğunluğuna göre burada "adalet" ile kastedilen; nafaka, mesken, hüsn-i muâsseret, kasm ${ }^{58}$, cima ${ }^{59}$, maddi veya manevi zarar vermeme vs. gibi konularda kocanın karıları arasında eşit davranmasıdır. ${ }^{60}$ Çünkü sevgi ve

ihtiyar dışında kendiliğinden oluşan durumlarda kocanın eşleri arasında adaletli davranmasıdır. (Elmalılı, Hak Dini, 3: 1487.)

${ }^{58}$ Fikıh literatüründe kocanın kudreti dâhilinde olan hususlarda, geceleme ve sohbet konusunda ayırım yapmaksızın eşleri arasında adil ve eşit davranmasına "kasm" denilmektedir. (Muhammed Ravvâs Kal'acî-Hamid Sâdık Kuneybî, "Kasm", Mu'cemü lüğati'l-fukhâ, (Beyrut: Daru'n-nefâis, 1985), 363; Erdoğan, "Kasm”, 233.)

Kasm'da eşler arasında adaleti gözetmek vaciptir. Buna göre kocanın, eşleri arasında gece nöbetleri tayin ederek her biri ile geçireceği nöbetin gecesini/veya gündüzünü tayin etmesi ve buna riayet etmesi gerekmektedir. Ancak kocanın gece nöbetini geçireceği karısı ile cimada/cinsel ilişkide bulunması şart değildir. Bununla birlikte koca, eşleri arasında takbil ve takarrüb (öpme/sevişme ve cinsel iliş̧i) gibi konularda da eşitliği gözetmek zorundadır. Kasm konusunda koca eşleri arasında adaleti gözetmezse, haklarından mahrum olan karının mahkemede dava açma ve hakkını arama hakkı vardır. Açılan davada hâkim eşlerinin maddi ve manevi haklarını gözetmesi hususunda kocaya gerekli uyarıları yapar. Ancak uyarılara rağmen koca gece nöbetinde (kasm) eşleri arasında adaleti gözetmezse, hâkimin erkeği/kocayı hapis dışında her hangi bir şey ile (örneğin para ve kırbaç cezası ile taziren) cezalandırması mümkündür. (Konuyla ilgili geniș bilgi için bkz. Bilmen, Hukuk-ı İslâmiyye ve Istılahât-ı Fıkhiyye Kamusu, 2: 160-165; Attâr, Teaddüdü'z-zevcât, 224-241; Ali-Ögüt, “Çok Evlilik”, 8: 366.

Ahmed Hamdi Akseki, gece nöbetine (kasm) riayet etmekle ile ilgili fikıh kitaplarına atfen şöyle bir bilgi nakletmektedir:

"Nafakada olduğu gibi gece nöbetinde eşitliğe riayet etmek erkek üzerine vaciptir... Fıkıh kitaplarında açıça bildirildiğine göre erkek, nöbeti olan kadının hanesine girmek istediği zaman kadın evin kapısını kapatırsa, erkeğin başka birisinin hücresine gitmeyerek o kadının hücresinin önünde yatması vaciptir. Meğerki soğuk veyahut diğer bir mani ola..." (Akseki, "İslâmiyet ve Teaddüd-i Zevcât", 309-310.)

59 Kadının kocası üzerindeki haklarından biri de cima, yani cinsel ihtiyaçlarının giderilmesidir. (el-Mevsûâtü'l-fikhiyye, "Nikāh", Vizâratü'l-evkâf ve'ş-șuûni'd-dîniyye, (Kuveyt: 2002), 41: 318) Malikilere göre bu koca üzerine vaciptir. (Bu konudaki farklı görüşler için bkz. Zühaylî, el-Fıkhü'l-islâmî, 7: 329-330.)

İnsanın ruhi ve manevi ihtiyaçları kadar cinsellik gibi bedeni ihtiyaçları da vardır. $\mathrm{Bu}$ anlamda cinsellik, fıtrî olup insanın doğasında ve evliliğin tabiatından olan bir olgudur. Dolayısıyla eşler arasında uyumun ve sağlıklı geçimin olabilmesi için erkek veya kadın her iki eşin de meşru bir şekilde cinsel ihtiyaçlarını karşılaması gerekir. Aksi halde, cinsel hayatın olmadığı bir evliliğin sağlıklı ve huzurlu bir şekilde yürümesi mümkün değildir. (Ali Rıza Demircan, "Ailede Cinsel Hayat", Aile ve Eğitim-Tartışmalı İlmi Toplantı-, (24-25 Nisan 2010) İstanbul: 2010), 133-136.) Dolayısıyla evlilikte cinsellik bir ihtiyaç olduğu kadar, eșlerin birbirlerinin cinsel ihtiyaçlarını gidermeleri karşılıklı haklarından ve vazifelerinden biridir. (Hayreddin Karaman, Anahatlarıyla İslâm Hukuku, (İstanbul: Ensar Neşriyat, 2011), 2: 97; Ali Bardakoğlu, "Haramlar ve Helaller", İlmihal (İslâm ve Toplum), (Ankara: Türkiye Diyanet Vakfı Yayınları, 2002), 2: 126-127.) Nitekim ilgili ayetlerde eşlerin birbirlerinde maddi ve manevi olarak sükûnet/huzur bulduğu (er-Rum, 30/21) ve birbirlerini zina vs. gibi gayr-i meşru ilişkilerden koruyan bir örtü/kalkan (el-Bakara, 2/187) olduğu ifade edilmiștir.

${ }^{60}$ Kurtubî, el-Câmi', 6: 37; Elmalılı, Hak Dini, 2: 1281; Zeydan, el-Mufassal fí ahkâmi'l-mer'e, 6: 288; Ali-Öğ̈̈t, “Çok Evlilik", 8: 366. Ayrıca bkz. Osmanlı Hukuk-ı Aile Kararnamesi, md. 73-74. 
merhamet gibi konularda kocanın eşleri arasında manevi adaleti gözetmesi kudreti dâhilinde olan bir durum değildir. Nitekim ayette, "Allah, bir kimseyi ancak gücünün yettiği şeyle yükümlü kılar" (el-Bakara, 2/286) denilmektedir. 61

Diğer taraftan erken dönem müfessirlerden Dahhâk (ö. 105/723) ${ }^{62}$ ve bazı İslâm hukuku araştırmacılarına göre maddi adalet ile birlikte manevi adalete riâyet edilmesi, yani eşler arasında sevgide ve muhabbette de adil/eşit davranılması gerekmektedir. Nitekim ilgili ayette, "Ne kadar uğraşırsanız uğraşın, kadınlar arasında adaleti yerine getiremezsiniz..." (enNisa, 4/129) buyrularak bunun asla mümkün olamayacağının belirtilmesi ve tek kadınla evliliğin (en-Nisa, 4/3) tavsiye edilmesi ayette maddi adalet ile birlikte manevi adaletin de kastedildiğini göstermektedir. ${ }^{63}$

Elbette maddi adalet ile birlikte manevi adaletin de gözetilmesi önemlidir. Ancak, ayette kişinin iradesi dışında tezahür eden manevi (sevgi) adaletten ziyade, kişinin irade ve takdirinde bulunan maddi adaletin kastedilmiş olması ile ilgili cumhurun görüşünün daha isabetli olduğu izahtan varestedir. ${ }^{64}$ Nitekim "... Ne kadar uğraşırsanız uğraşın, kadınlar arasında adaleti yerine getiremezsiniz... " (en-Nisa, 4/129) ayetinin hükmü gereğince, ne kadar gayret etse de kocanın eşleri arasında manevi adaleti tesis etmesi mümkün değildir.

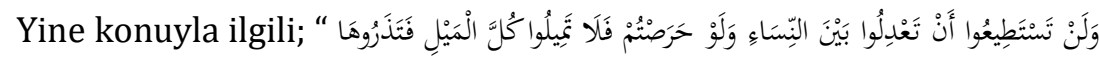

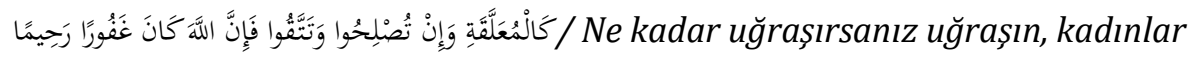
arasında adaleti yerine getiremezsiniz. Öyle ise (birine) büsbütün gönül verip ötekini (kocası hem var, hem yok) askıda kalmış kadın gibi bırakmayın. Ĕger arayı düzeltir ve Allah'a karşı gelmekten sakınırsanız, şüphesiz Allah çok bağışlayıcı ve çok merhamet edicidir" (en-Nisa, 4/129) ayetinde eşler arasında sevgiye dayalı manevi adaletin asla gerçekleştirilemeyeceği ifade edilmekle birlikte, dolaylı olarak gece nöbetine (kasm) dayalı maddi adalete riayet edilmesi de istenilmektedir. 65

Şu halde, ilgili ayetlerden anlaşıldığına üzere İslâm hukukunda çok eşliliğin meşruiyeti, erkeğin eşleri arasında maddi adaleti sağlayabilecek bir irade ve karaktere sahip olması şartına bağlanmıştır. ${ }^{66}$ Buna göre maddi

${ }^{61}$ Elmalılı, Hak Dini, 3: 1487; Ebû Zehra, el-Ahvâlü'ş-şahsiyye, 90; Zühaylî, el-Fılkhü'l-islâmî,

7: 168 .

${ }^{62}$ Bkz. Kurtubî, el-Câmi', 6: 37.

${ }^{63}$ Carullah, Hatun, 73-74; Topaloğlu, İslâmda Kadın, 99-100.

${ }^{64}$ Elmalılı, Hak Dini, 3: 1487; Şelebî, Ahkâmü'l-üsre, 237; Zeydan, el-Mufassal fí ahkâmi'lmer'e, 6: 288.

${ }^{65} \mathrm{Krş.} \mathrm{Elmalıl,} \mathrm{Hak} \mathrm{Dini,} \mathrm{3:} 1487$.

${ }^{66}$ Reşid Rıza, Tefsîrül'-Menâr, 4: 348-349; Akseki, “İslâmiyet ve Teaddüd-i Zevcât", 303. 
adaleti sağlama konusunda yetersiz olan, bir başka ifade ile eşlerine haksızlık ve zülüm yapma potansiyeline sahip olan erkeklerin aynı anda birden fazla kadınla evlenmesi caiz değildir. ${ }^{67}$ Burada kocanın eşleri arasında maddi adaleti gerçekleştirip gerçekleştiremeyeceği konusunda yakîn, yani kesin bir bilgi şart olmayıp bu konuda zann-ı galip yeterlidir. Dolayısıyla eşleri arasında maddi adaleti sağlayamayacağı konusunda zann-ı galib hâsıl olan erkeğin aynı anda birden fazla kadınla evlenmesi haram olmaktadır.68

Buna göre şu veya bu şekilde eşleri arasında maddi adaleti gerçekleştirmekten endişe eden erkeklerin mevcut eşleri üzerine ikinci bir kadınla evlenmemeleri ve "... Sayet (o kadınlar arasında da) adaletli davranmayacağınızdan korkarsanız, o takdirde bir tane alın (bir kadınla evlenin)..." (en-Nisa, 4/3) ayetinin hükmü gereğince tek eş ile yetinmeleri gerekmektedir. ${ }^{69}$ Diğer taraftan koca eşleri arasında maddi adaleti gözetse de manevi adaleti gözetme konusunda başarılı olamayacak ve manevi adaletsizliğe bağlı olarak eşleri arasında veya eșleri ile kendisi arasında bazı haksızlıkların (zulüm) ve (kıskançlık gibi) manevi huzursuzlukların yaşanmasına zemin hazırlayacaktır. ${ }^{70}$ Kur'an'da tek eşliliğin tavsiye ve teşvik edilmesi (bk. en-Nisa, 4/3) de bunu göstermektedir. ${ }^{71}$ Çünkü çok eşlilik, doğası gereği eşler arasında kıskançlığa ve karı-koca arasındaki ülfet ve muhabbetin gitmesine sebep olacaktır. ${ }^{72}$

Yukarıdaki açıklamalardan da anlaşılacağı üzere; Kur'an'da, "Ne kadar uğraşırsanız uğraşın, kadınlar arasında adaleti yerine getiremezsiniz" (en-

\footnotetext{
${ }^{67}$ Sibâî, el-Mer'e beyne'l-fikhi ve'l-kânûn, 80; Zeydan, el-Mufassal fí ahkâmi'l-mer'e, 4: 287. ${ }^{68}$ Reșid Riza, Hukûku'n-nisâ, fi'l-İslâm, (Beyrut: el-Mektebetü'l-islâmî, 1984), 65; Şelebî, Ahkâmü'l-üsre, 235; Zeydan, el-Mufassal fí ahkâmi'l-mer'e, 6: 288. Ayrıca bkz. Akseki, "İslâmiyet ve Teaddüd-i Zevcât", 306.

${ }^{69}$ Cessâs, Ahkâmü'l-Kur'ân, 2: 346; İbnü'l-Arabî, Ahkâmü'l-Kur'an, thk./tlk., Muhammed Abdülkadir Ata, (Beyrut: Dâru'kütübi'l-ilmiyye, 2003), 1: 408; İbn Âșûr, et-Tahrîr, 4: 225226; Elmalılı, Hak Dini, 2: 1281-1282; Reșid Rıza, Hukûku'n-nisâ, 65-66; Bilmen, Hukuk-ı Islâmiyye ve Istılahât-ı Fıkhiyye Kamusu, 112; Ebû Zehra, el-Ahvâlü'ş-şahsiyye, 90; Attâr, Teaddüdü'z-zevcât, 159; Zeydan, el-Mufassal fí ahkâmi'l-mer'e, 6: 287; Zühaylî, el-Fıkhü'lislâmî, 7: 168.

${ }^{70}$ Akseki, “İslâmiyet ve Teaddüd-i Zevcât", 304, 308, 310-311. Bu konuda meşhur ahlak bilimcisi, fakih ve müfessir İslâm âlimi Kınalızâde Ali Efendi, (ö. 979/ 1572) Ahlâk-ı Alâ̂̂ isimli eserinde şöyle demektedir: "Erkek karısı ile yetinip üzerine evlenmemelidir; çünkü iki evlilik kıskançlık ve geçimsizlik doğurur... Evde erkek, tende can gibidir; iki tene bir can olmadığı gibi iki kadına da bir erkek yakıșmaz." Bkz. Mustafa Çağrıcı, "İslâm Ahlakı", İlmihal (İslâm Ve Toplum), (Ankara: Türkiye Diyanet Vakfı Yayınları, 2002), 2: 527.

71 İbn Âșûr, et-Tahrîr, 4: 228. Ayrıca bkz. Cessâs, Ahkâmü'l-Kur'ân, 1: 409-410, 2: 348; Osmanlı Hukuk-ı Aile Kararnamesi (Esbâb-ı Mûcibe Lâyihası/Nikâh-ı Mükreh), 91; M. Akif Aydın, İslam-Osmanlı Aile Hukuku (Esbâb-ı Mûcibe Lâyihası /Nikâh-ı Mükreh), (İstanbul: MÜİFV Yayınları, 1985), 276.

72 İbnü'l-Arabî, Ahkâmü'l-Kur'ân, 1: 409-410. Ayrıca bkz. Bkz. Osmanlı Hukuk-ı Aile Kararnamesi (Esbâb-ı Mûcibe Lâyihası/Nikâh-ı Mükreh), 91; Aydın, Aile Hukuku (Esbâb-ı Mûcibe Lâyihası/Nikâh-ı Mükreh), 276; Çağrıcı, “İslâm Ahlakı”, İlmihal, 2: 527.
} 
Nisa, 4/129) şeklinde ifade edilen "eşler arasında adaletin gözetilmesi" şartı, Şâri'in maksadına ve maslahata uygun olarak çok eşlilik ruhsatını kullanmak isteyen erkekler için yerine getirilmesi gerçekten zor bir şarttır. ${ }^{73}$ Ancak, nefsani arzularını ve kişisel maslahatını/zevkini düşünen erkelerin uygulamada bu şartı dikkate almadıkları da bilinen bir gerçektir. Dolayısıyla Ahmed Hamdi Akseki'nin (1887-1951) haklı olarak sorduğu gibi; "eşleri arasında adaleti ifaya kadir olamayacaklarını bildikleri halde sırf şehvetlerini tatmin etmek isteyen erkeklerin, aynı anda birden fazla kadınla evlenmesine İslâm nasıl cevaz verebilir?"74

\section{b. Nafaka: Eşlerin Geçimini Temin Edebilme (Mali Yeterlilik) Şartı}

Çok eşlilik hakkının kullanılmasının meşru olmasının ikinci temel şartı, önceki ve yeni tüm eşlerinin nafakasını ${ }^{75}$ temin etme konusunda ekonomik güç ve imkâna sahip olmaktır. Bu konuda ilgili naslarda doğrudan ileri sürülen bir şart olmamakla birlikte, çok eşliliğin mubah/meşru olmasına dayanak teşkil eden ilgili ayette (Nisa, 4/3) geçen bazı ifadeler ve genel olarak evlilikte kocanın nafaka yükümlülügünden bahseden ayetler ${ }^{76}$, dolaylı olarak mali yeterliliğin (nafakaya güç yetirebilmenin) şart olduğunu göstermektedir. ${ }^{77}$

Nitekim bazı İslâm hukukçuları ve müfessirler, çok eşliliği mubah kılan

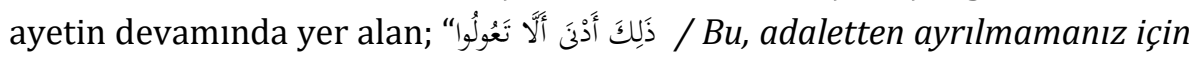

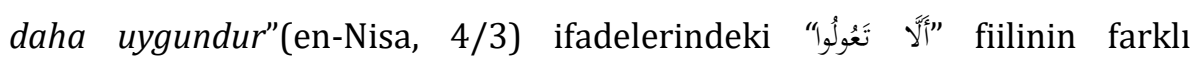
anlamlarından hareketle Kur'an'ın çok eşliliğin cevazı için getirmiş olduğu "kocanın eşleri arasında maddi adaleti gözetmesi" şartına ilaveten; "eşlerin nafakasını temin edebilecek mali güce sahip olma" şartının da bulunması gerektiğini söylemektedirler. ${ }^{78}$

\footnotetext{
${ }^{73}$ Akseki, "İslâmiyet ve Teaddüd-i Zevcât", 304, 312; Attâr, Teaddüdü'z-zevcât, 165-166.

${ }^{74}$ Akseki, "İslâmiyet ve Teaddüd-i Zevcât", 310.

${ }^{75}$ Evlilik nafakasının kapsamına, yiyecek-içecek, giyecek, mesken, tedavi ve ilaçlar ile ihtiyaç olması ve emsali kadınların bulundurması halinde hizmetçi de girmektedir. Evlilik nafakası hakkında bkz. Karaman, Anahatlarıyla İslâm Hukuku, 2: 100-102; Celal Erbay, "Nafaka", Türkiye Diyanet Vakfı İslâm Ansiklopedisi (Ankara: TDV Yayınları, 2006), 32: 282-283.

76 Örnek olarak bkz. en-Nisa, 4/3, 34; en-Nur, 24/33.

${ }^{77}$ Attâr, Teaddüdü'z-zevcât, 179-180.

78 İbnü'l-Arabî, Ahkâmü'l-Kur'ân, 1: 408, 409; Muhammed Seyyid Bey, Fıkıh Usulü (Giriș), Yay. Haz: Hasan Karayiğit, (İstanbul: Düşün Yayınları, 2010), 134; Elmalılı, Hak Dini, I2: 1282; İbn Âşûr, et-Tahrîr, 4: 228-229; Ebû Zehra, el-Ahvâlü'ş-şahsiyye, 90-91; Zeydan, elMufassal fí ahkâmi'l-mer'e, 6: 287-288; Karaman, Anahatlarlyla İslâm Hukuku, 2: 68. Ayrıca bkz. Saffet Köse, İslâm Hukukunda Hakkın Kötüye Kullanılması, İstanbul: MÜİFAV Yayınları, 1997), 153; Faruk Beșer, Güncel Meseleler Dini Çözümler, (İstanbul: Nun Yayıncılık, 2008), 190-192; Ali-Öğüt, "Çok Evlilik", 8: 366; Nihat Dalgın, İslam Hukukunda Boşama Yetkisi, (Samsun: Etüt Yayınları, 1999), 191.
} 
Bu yorumu yapan İslâm âlimlerine göre ayeti; "Bu sizin çoluk çocuğunuzun artıp geçim derdine düşmemeniz için en uygun yoldur" şeklinde anlamak da mümkündür. ${ }^{79}$ Nitekim Elmalılı (ö. 1942), ilgili ayetin

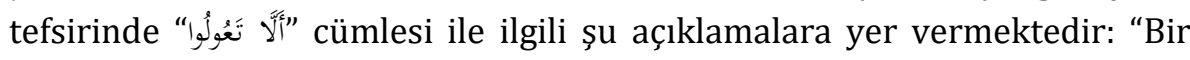
kadın nikâhı (bir kadınla evlenmeniz), cevretmemenize (zulmetmemenize) daha elverişlidir. Yalnız bir kadının hakkını gözetmek elbette daha kolaydır. Bunda cevre düşmemek ihtimali daha akrebtir. Bu cümleden "fakr-ü zarurete düşmemenize, yani iktisadınıza daha elverişlidir" manası da anlaşılmıştır ki... bu mana bir ma'nâi lâzımî olmak üzere gösterilmiştir." 80

Buna göre ilgili ayette dolaylı olarak erkeğin birden fazla kadınla evlenmesinin çok çocuk sahibi olmasına, çok çocuk sahibi olmanın da nafaka yükümlülüğünü artıracağına ve dolayısı ile kocanın, eşlerinin ve çocuklarının nafakasını temin etme konusunda acziyete düşeceğine işaret edilmektedir. ${ }^{81}$ Bundan dolayıdır ki ayette, "o takdirde bir tane alın/bir kadınla evlenin... Zira bu, adaletten ayrılmamanız (yani nafaka temininden aciz kalarak eşleriniz ve çocuklarınız arasında zulüm/haksızlık yapmamanız) için daha uygundur" (enNisa, 4/3) denilmiştir. 82

İslâm hukukçularının çok eşliliğin mubah olabilmesi için "kocanın nafakaya güç yetirebilmesi" şartı ile ilgili istidlâl ettikleri ayetlerden biri de genel olarak evlilikte kocanın nafaka yükümlülüğünden bahseden şu ayettir:

"Evlenmeye güçleri yetmeyenler de, Allah kendilerini lütfuyla zengin edinceye kadar iffetlerini korusunlar." (en-Nur, 24/33)

$\mathrm{Bu}$ ayete göre, (dolaylı da olsa) ailede nafakayı temin etmekle/aileyi geçindirmekle yükümlü olan kocanın (en-Nisa, 4/34) ilk evliliği için ailenin nafakasını temin etme gücüne ve imkânına sahip olması şart koşulmaktadır. Erkeğin ilk evliliğinde nafakayı temin etme kudretine sahip olması şart olunca, ikinci eşi için bu durum evleviyetle şart olmaktadır. ${ }^{83}$

Bu konuda istidlâl edilen naslardan biri de şu hadistir:

"Gençler! Sizden kimin evlenmeye (bedeni ve mali) gücü yeterse hemen evlensin. Zira evlilik, gözü (harama bakmaktan) daha çok sakındıran ve irzl/namusu daha fazla koruyandir. Kimin de buna (mali) gücü yetmezse o da oruç tutsun; çünkü oruç, onun (șehvetini

\footnotetext{
${ }^{79}$ Attâr, Teaddüdü'z-zevcât, 179; .Ali-Öğüt, "Çok Evlilik”, 8: 366.

${ }^{80}$ Elmallı, Hak Dini, 2: 1282.

${ }^{81}$ Attâr, Teaddüdü'z-zevcât, 179; Ali-Ögüu,, “Çok Evlilik", 8: 366.

${ }^{82}$ Ebû Zehra, el-Ahvâlü'ș-șahsiyye, 91; Zeydan, el-Mufassal fî ahkâmi'l-mer'e, 6: 289.

83 Zeydan, el-Mufassal fí ahkâmi'l-mer'e, 4: 288-289; Şelebî, Muhammed Mustafa, Ahkâmü'l-üsre, 235.
} 
İbrahim YILMAZ

\section{teskin) için kalkan gibidir." ${ }^{\prime 84}$}

Bu hadis, -ilk evliliği olmasına rağmen- evlenmek için yeterli maddi imkânı olmayan erkeklerin evlenmesinin caiz olmadığına delalet etmektedir. Dolayısıyla evli olup da birinci eşle birlikte ikinci eşinin nafakası için yeterli maddi imkâna sahip olmayan erkeklerin ikinci evlilik yapmaları evleviyetle mubah/caiz olmamaktadır. 85

Şu halde ikinci eşin nafakasını temin etmek için yeterli mali/maddi imkâna sahip olmayan bir erkeğin, mevcut karısının üzerine ikinci bir kadınla evlenmek istemesi başkasının yani, hem birinci karısının hem de ikinci karısının hakkına gereken önemi göstermemektir. Bu ise bir nevi zülümdür. Zülüm ve başkasının hakkını çiğnemek ise İslâm'da caiz değildir. 86

Özetle ifade etmek gerekirse; konuyla ilgili ayetler (en-Nisa, 4/3, 129), İslâm hukukunda çok eşliliğin mubah olduğunu gösterdiği gibi bunun "eşler arasında adaleti gözetmek" şartına ilaveten "eşlerinin nafakasını temin etme kudretine sahip olmak" gibi bazı şartlarla kayıtlı olduğunu da göstermektedir. ${ }^{87}$ Ancak şu ayrıma da dikkat çekmek uygun olacaktır: Burada çok eşliliğin meşruiyetini mubah kılan "nafakaya güç yetirme" şartı ile erkeğin yeterli mal varlığına ve zenginliğe sahip olması değil, sağlığının ve sıhhatinin çalışarak eşlerinin nafakasını temin etmeye elverişli olması kastedilmektedir. Aksi halde çok eşliliği meşru kılan "nafakaya güç yetirme" şartı ile yeterli mali zenginliğe sahip olmanın şart koşulması, çok eşliliği gerekli kılan diğer şatların bulunması halinde zenginlik şartını hali hazırda taşımayan erkeklerin bu ruhsattan yaralanması mümkün olmayacaktır. 88

\footnotetext{
${ }^{84}$ Buhârî, "Savm", 10; "Nikâh, 2,3; Müslim, "Nikāh", 1,3; Ebû Dâvûd, "Nikāh",1; Tirmizî, "Nikāh", 1; Nesâî, "Nikāh", 3, "Sıyâm", 43; İbn Mâce, "Nikāh", 1.

${ }^{85}$ Zühaylî, el-Fıkhü'l-islâmî, 7: 168; Şelebî, Ahkâmü'l-üsre, 235; Zeydan, el-Mufassal fî ahkâmi'l-mer'e, 6: 289.

${ }^{86}$ Zeydan, el-Mufassal fî ahkâmi'l-mer'e, 6: 289.

${ }^{87}$ Karaman, Anahatlariyla İslâm Hukuku, 2: 68.

${ }^{88}$ Attâr, Teaddüdü'z-zevcât, 180-182.

Ahmed Hamdi Akseki, evlilikte nafakayı temin etmeye güç yetirme açısından erkekleri; zengin, orta halli ve fukara olmak üzere üç sınıfa ayırmakta ve özetle şöyle demektedir: "(1) İlgili ayet ve hadislerde nafakaya güç yetiremeyen erkeklerin sabretmesi tavsiye edildiğinden fukara olan erkekler evlilik hukukunu hakkıyla yerine getirmekten acizdir. Bu yüzden onların tek bir kadınla da olsa evlenmeleri doğru değildir. Ancak İslâm bu sınıfta yer alan fakir erkeklere zenginlerin yardımda bulunmasını ve evlendirilmesini tavsiye etmektedir. (2) Orta halli olan erkeklerin ise yalnız bir kadınla yetinmeleri vacip kılınmıştır. Bunların birden fazla kadınla evlenmeleri mahzurludur. (3) Zengin erkeklere gelince bundan maksat, aynı anda birden fazla kadının nafakasını temin etmeye güç yetiren erkeklerdir. İște şer'-i şerifin belirlediği şartlara riayet etmek şartı ile zengin erkeklerin birden fazla kadın ile evlenmesi mubahtır. (Akseki, "İslâmiyet ve Teaddüd-i Zevcât", 306-307.)
} 


\section{2. Çok Eşliliğe Ruhsat Veren (Veya Bunu Mendup ve Vacip Kılan) Özel Durumlar}

İslâm hukukunda çok eşlilik aslen mubah olmakla birlikte bazı durumlarda çok eşlilik mendup veya vacip de olabilmektedir. ${ }^{89}$ Bu yüzden İslam hukukçuları çok eşliliğe ruhsat veren bireysel ve toplumsal bazı özel durumlar (sebepler/şartlar) üzerinde durmuşlardır. ${ }^{90}$

İslâm hukukçuları çok eşliliğe ruhsat veren durumları, toplumsal sebepler ve bireysel sebepler olmak üzere iki grupta ele almışlardır;

Buna göre; savaş, doğal afet gibi bir sebepten veya tabii olarak erkekkadın nüfusunun dengesiz artmasından dolayı toplumda evlilik çağına gelmiş erkeklerin nüfusunun azalarak kadınların nüfusunun erkeklerin nüfusundan çok fazla olması; savaş veya doğal afet gibi bir sebepten dolayı dul ve kimsesiz kalan bakıma muhtaç kadınların maddi ve manevi ihtiyaçlarının giderilmesi; toplumdaki nüfus oranının tabi olarak azalmasından dolayı neslin artmasına ihtiyaç duyulması gibi sebepler, çok eşliliğe ruhsat veren toplumsal sebeplerdendir.

Buna mukabil, kadının kısır olması veya müzmin hasta olması; fizyolojik/biyolojik olarak kusurlu olması; erkeğin cinselliğe aşırı arzu duyması sebebiyle zinaya düşme tehlikesinin bulunması gibi durumlar ise çok eşliliği ruhsat veren özel sebeplerdendir.

Çok eşliliğe ruhsat veren şartlar/sebepler, elbette yukarıda sayılan durumlarla sınırlı değildir. Nitekim bu sebepler kişilere göre değiştiği gibi, bunu gerekli kılan şartlar da toplumlara göre farklılık gösterebilir. Burada amaç, bireysel ve toplumsal maslahatı gerçekleştirmek ve insanların zina gibi gayr-i meşru yollara başvurmasını önlemektir. Dolayısıyla zamana ve zemine göre çok eşliliği mubah veya gerekli kılan yeni veya farklı gerekçelerin dikkate alınması da mümkündür. ${ }^{91}$

Burada şu gerçeği ifade etmek gerekir ki çok eşlilik, sadece erkeğin değil aynı zamanda kadının da haklarını ve ihtiyaçlarını gidermek için meşru kılınmış bir ahlaki ve hukuki kurumdur. Yukarıda sayılan gerekçelerin bulunması halinde çok eşliliğe (teaddüd-i zevcât’a) izin verilmemesi,

\footnotetext{
${ }^{89}$ Carullah, Hatun, 74; Elmalılı, Hak Dini, 2: 1290; Ebû Zehra, el-Ahvâlü'ş-șahsiyye, 95.

${ }^{90}$ Bkz. İbn Âșûr, et-Tahrîr, 4: 226-227; Reşid Rıza, Hukûku'n-nisâ, 66-68; Muhammed Zâhid el-Kevserî, Makālâtü'l-Kevserî, (Kahire: el-Mektebetü't-tevfîkıyye, ty.), 207-209; Zerkâ, el-Medhal, 1: 36; Bilmen, Hukuk-ı İslâmiyye ve Istılahât-ı Flkhiyye Kamusu, 2: 113; Carullah, Hatun, 74-77; Sibâî, el-Mer'e beyne'l-fikhi ve'l-kânûn, 67-73; Attâr, Teaddüdü'zzevcât, 21-49; Zeydan, el-Mufassal fỉ ahkâmi'l-mer'e, 6: 289-291; Karaman, İslâm'da Kadın ve Aile, 393-394; Zühaylî, el-Fıkhü'l-islâmî, 7: 169-170; Topaloğlu, İslâmda Kadın, 101-102; Ali-Öğüt, "Çok Evlilik", 8: 366; Ali Rıza Demircan, "Çok Eşlilik", Hz. Peygamber ve Aile Hayatı, Yay. Haz. İsmail Lütfi Çakan, (İstanbul: İlmi Neșriyat, ty.), 248-251.

${ }^{91}$ Attâr, Teaddüdü'z-zevcât, 22, 47.
} 
"teaddüd-i nisâ" denilen birden fazla kadınla gayr-i meșru ilişki yaşamanın ve toplumda fuhşun yaygınlaşmasının yolunu açacaktır. ${ }^{92}$

\section{Değerlendirme}

Kur'an'da yer alan ilgili naslar, İslâm hukukunda erkeğin aynı anda birden fazla (en fazla dörde kadar) kadınla evlenmesinin mubah/meşru olduğunu göstermektedir. Ancak konuyla ilgili naslar incelendiğinde İslâm hukukunda çok eşliliğin mubah/meşru olabilmesinin; "eşler arasında adaleti gözetmek" (en-Nisa, 4/3, 129) ve "eşlerin nafakasını temin etmeye güç yetirebilmek" (en-Nisa, 4/3, 34; en-Nur, 24/33) ${ }^{93}$ olmak üzere iki temel şarta bağlandığı görülmektedir. Diğer taraftan İslâm hukukunda meşruiyeti nass ile sabit olan çok eşlilik, evlenme ehliyetine sahip her erkeğin uygulaması gereken bir emir ve aslî bir hüküm (azimet) değildir. Aksine bazı ihtiyaç ve zaruretler sebebiyle belirli şartların ve gerekçelerin bulunması halinde başvurulması gereken istisnâî bir ruhsat hükmüdür. ${ }^{94}$

İlgili naslarda şartlar ve doktrinde yer alan gerekçeler birlikte değerlendirildiğinde İslâm hukukunda çok eşliliğin meşru/mubah olabilmesi için şu üç temel şartın bulunması gerektiğini söylemek mümkündür95;

1. Eşler arasında adalete riayet etmek,

2. Eșlerin nafakasını temin edebilecek yeterli mali güce/imkâna sahip olmak,

3. Ferdi veya toplumsal ihtiyaç veya zaruretin bulunması.

Buna göre yukarıda sayılan bu üç șarttan ilk ikisi, çok eșliliğin meşruiyet şartı, üçüncü maddede sayılan şart ise çok eşliliğin ruhsat şartı olmaktadır.

Şu halde İslâm hukukunda belirli şartlar ve gerekçeler çerçevesinde meşru kılınan çok eşlilik hakkının istismar edilmemesi için yukarıda sayılan şartlara riayet edilmesi gerekmektedir. Aksi halde İslâm'ın belirli şartlar ve gerekçelerden dolayı meşru kıldığı çok eşliliğin, birey, aile ve toplum açısından bazı sıkıntılara, huzursuzluklara ve haksızlıklara sebep olması kaçınılmazdır. ${ }^{96}$ Dolayısıyla belirli şartlar ve gerekçeler çerçevesinde İslâm hukukunun meşru kabul ettiği çok eşlilik, bireysel ve toplumsal maslahatın giderilmesine yönelik ahlakî ve hukukî bir kurum olmaktadır. Buna göre

92 Demircan, "Çok Eşlilik", 252.

${ }^{93}$ Ayrıca bkz. Buhârî, "Savm", 10; "Nikâh, 2,3; Müslim, "Nikāh", 1,3; Ebû Dâvûd, "Nikāh",1; Tirmizî, "Nikāh", 1; Nesâî, "Nikāh", 3, "Siyâm", 43; İbn Mâce, "Nikāh”, 1.

${ }^{94}$ Kaynakça için bkz. I. Cok Eșliliğin (Teaddüd-i Zevcât) Meșruiyeti.

${ }^{95}$ Ebû Zehra, el-Ahvâlü'ş-şahsiyye, 90-93; İbn Âșûr, et-Tahrîr, IV, 226-227; Zerkâ, elMedhal, I, 36; Karaman, Anahatlarıyla İslâm Hukuku, 2: 68; Apaydın, "İmam Nikâhı Uygulaması", 379; Demircan, “Çok Eșlilik", 248-251.

${ }^{96}$ Carullah, Hatun, 74 
yukarıda sayılan şartlara uygun olarak gerçekleşen çok eşlilik, hiçbir haksızlığa sebep olmayacağı gibi, toplumda yaygınlık kazanan pek çok haksızlığın ve zina gibi gayr-i meşru ilişkilerin de yolunu kapayacaktır. ${ }^{97}$

$\mathrm{Bu}$ açılklamalardan sonra İslâm hukukunda çok eşliliğin meşru kılınması ile ilgili şunları söylemek mümkündür; 98

1. Çok eşlilik, belirli şartların ve sebeplerin bulunması halinde meşru kılınmış bir ruhsat hükmüdür.

2. Çok eşlilik, bireysel veya toplumsal maslahatın bulunmasına bağlı bir uygulamadir.

3. Çok eşlilik, "eşler arasında adaletin gözetilmesi" şartına bağlıdır.

4. Çok eşlilik, "eşlerin nafakasını temin etme" şartına bağlıdır.

5. Çok eşlilik, daha büyük zararlardan ve kötülüklerden kurtulmak mülahazası ile (daha önce var olan uygulama tadil edilerek) meşru kılınmıştır.

6. Çok eşlilik, eşler açısından zarar ve haksızlıklara (mefsedetlere) vesile olması halinde meşru değildir.

Yukarıdaki hususlar dikkate alındığında, İslâm hukukunda çok eşliliğin uygulanabilmesi, mevcut eşin rızasına ve iznine tabi olduğu anlaşılmaktadır. ${ }^{99}$ Diğer taraftan bu şartlar içerisinde hiç şüphesiz "kocanın eşleri arasında adaleti gözetmesi" şartı ile bireysel ve toplumsal maslahatın bulunup bulunmaması merkezi bir öneme sahiptir. Nitekim Elmalılı (ö.1942), Nisa, 4/3. ayetin tefsirinde bu gerçeği şöyle ifade etmektedir;

"O halde halinize göre, kadınlardan ikişer, üçer, dörde size helal ve hoş olanları, nikâh ediniz. (Bu durum) hem onları zarar ve tehlükeden sıyânete, hem de kendinizi zulm-ü tecavüzden vikayeye vesile olur. (Böylece) umumiyetle kadınlar, kimsesizlikten ve mebzuliyetten kurtulur. Siz de zina ve saire gibi günahlara, cevrlere düşmezsiniz. Ancak bunda da müteaddid kadınlar beyninde/arasında adaleti muhafaza etmek, birine diğerinden ziyade muamele etmemek lazımdır." 100

$\mathrm{Bu}$ konuda son dönem İslâm âlimlerinden Ahmed Hamdi Akseki (1887-1951) șu değerlendirmelerde bulunmaktadır:

\footnotetext{
${ }^{97}$ Akseki, "İslâmiyet ve Teaddüd-i Zevcât", 276-277, 312; Bilmen, Hukuk-ı İslâmiyye ve Istılahât-ı Fıkhiyye Kamusu, 2: 114; Carullah, Hatun, 77.

${ }^{98} \mathrm{Krş}$. Carullah, Hatun, 76.

99 İbn Kayyim el-Cevziyye, Zâdü'l-meâd fî hedyi hari'i-ıbâd, thk. Şuayb el-ArnavutAbdülkadir el-Arnavut, (Beyrut: Müessesetü'r-risâle, 1994), 5: 118; Osmanlı Hukuk-i Aile Kararnamesi, md. 38; Muhammed Hamidullah, "Müslümanlarda Hukuk Felsefesi", trc. İ. Kâfi Dönmez, İslâm Medeniyeti 4/4, (1980): 27-28.

${ }^{100}$ Bkz. Elmalılı, Hak Dini, 2: 1281.
} 
"Her kim şu iki ayeti (Nisa, 4/2-3) yakînen bilir ki, İslâmiyyette teaddüd-i zevcât, kendisinde pek şiddetli tazyîk gösterilen bir şeydir. İhtiyaç hissettikten sonra adâlet edeceğine emin olmak şartıyla mubah olan zaruretlerden bir zarurettir. Kur'an-ı Kerim'de zikredilen bu kadar kayıt ve şart düşünülürse anlaşılır ki, bugün birçok kimselerde görülen teaddüd-i zevcât, katiyen meşru değildir. Çünkü şer'-i şerifin itibar ettiği şartlar bulunmamaktadır." 101

İslâm hukukçuları çok eşliliğin meşru olabilmesi için naslarda belirtilen "adaleti gözetme" ve "nafakayı temin etmeye güç yetirebilme" şartının birlikte bulunması gerektiği konusunda ittifak etmişlerdir. Zira bunlardan biri diğerinin bulunmasını zorunlu kılmaktadır. Dolayısıyla evlendiğinde eşleri arasında adaleti gözetemeyeceğini veya eşlerinin nafakasını temin edemeyeceğini bilen bir erkeğin mevcut karısının üzerine ikinci bir kadınla evlenmesi caiz/meşru olmamaktadır. ${ }^{102}$

Bununla birlikte İslâm hukukçuları naslarda zikredilen "adaleti gözetme" ve "nafakayı temin etmeye güç yetirebilme" şartlarına riayet edilmeden mevcut eşin üzerine ikinci bir kadınla yapılan nikâh akdinin sahih/geçerli olacağını söylemektedirler. Şöyle ki, her ne kadar çok eşliliğin meşruiyeti için adaletin gözetilmesi ve nafakanın temin edilmesi şart koşulmuşsa da bu iki şart, nikâh akdinin sıhhat, yani geçerlilik şartlarından değildir. Dolayısıyla, bu iki şarta riayet edilmeden yapılan ikinci evlilik sahihtir. Ancak koca, eşleri arasında adaleti gözetmediği ve/ya eşlerinin nafakasını temin etmediği için zülüm işlemektedir ve bundan dolayı günahkârdır. Yaptığı bu haksızlığın hesabını Allah'a verecektir. ${ }^{103}$

İslâm hukukçuları "adaleti gözetme" ve "nafakayı temin etmeye güç yetirme" şartlarına riayet etmeyen erkeğin, karısının üzerine ikinci bir kadınla yaptı̆̆ı evliliğin sahih olmasını, diğer bir ifade ile fasit olmamasını iki şekilde gerekçelendirmektedirler: 104

Birincisi: akdin sıhhat veya fesadı; olması muhtemel şartlara ve durumlara göre değil mevcut şartlara göre değerlendirilir.

İkincisi: zulüm, vukuundan önce umûr-i nefsiyyeden, yani insanın

101 Akseki, "İslâmiyet ve Teaddüd-i Zevcât", 304. Ayrıca Durmuş, "Ahmed Hamdi Akseki'nin Birden Fazla Evlilik (Çok eşlilik) Konusundaki Yaklaşımı”, 267.

${ }^{102}$ Ebû Zehra, el-Ahvâlü'ş-şahsiyye, 91; Ebû Zehra, el-Muhâdarât fí akdi'z-zevâc ve eserih, 134. Ayrıca bkz. Akseki, "İslâmiyet ve Teaddüd-i Zevcât", 306; Șelebî, Ahkâmü'l-üsre, 235236; Karaman, Anahatlarıyla İslâm Hukuku, 2: 69; Karaman, İslâm'da Kadın ve Aile, 393. Ayrıca bkz. Cessâs, Ahkâmü'l-Kur'an, 2: 346, 348.

${ }^{103}$ Ebû Zehra, el-Ahvâlü'ş-șahsiyye, 91; Ebû Zehra, el-Muhâdarât fî akdi'z-zevâc ve eseruh, eserih, 135; Şelebî, Ahkâmü'l-üsre, 236. 
içerinde gizli olan bir durumdur. Akitlerin sihhat veya fesat şeklindeki hükmü ise gizli olan bir illete/sebebe bina edilemez. ${ }^{105}$

Diğer taraftan infak, rızıkla alakalı bir durumdur. İnsanın rızkının ne olacağını ise Allah bilir. Bundan dolayıdır ki akit esnasında erkeğin nafakaya muktedir olmaması, onun ileride eşlerinin nafakasını temin edemeyeceği anlamına gelmez. Dolayısıyla nafaka şartına riayet edilmemesi nikâh akdinin fesadını gerektirmez. ${ }^{106}$

Özetle ifade etmek gerekirse; İslâm hukukunda çok eşliliğin teşri kılınmasının amacı, erkeklerin cinsel arzularını tatmin etmek değil, bireysel ve toplumsal şartlarının bulunması halinde, kadınların maddi ve manevi hukukunu korumak, toplumda gayr-ı meşru ilişkilerin vukuu bulmasını önlemektir. ${ }^{107}$ Dolayısıyla "Kur'ân'da zikredilen şartlar içerisinde teaddüd-i zevcât gayet meşrudur, ma'kûldür. Âyetin hükmü her zaman ve mekânda bakidir." 108

İslâm hukukunda çok eşliliğin meşruiyeti, belirli şartların ve bazı özel durumların bulunmasına bağlı olmakla birlikte uygulamada buna riayet edilmediği de bilinen bir gerçektir. Bu yüzden uygulamada çok eşlilik hakkı istismar edilmeye açık bir konudur. Bundan dolayıdır ki tarihi süreçte çok eşliliğin kamu otoritesi tarafından sınırlandırılması gündeme gelmiştir. Günümüz İslam hukukçuları arasında da çok eşliliğin kamu otoritesi tarafından denetlenmesi ve/ya sınırlandırılması tartışılmaya devam etmektedir. 109

Diğer taraftan "zararın giderilmesi" ve "kamu yararının gerekli kılması" halinde İslâm hukukunda kamu otoritesinin mubahı (hukukî

\footnotetext{
${ }^{105}$ Akitlerde iradeyi beyan teorisi ile ilgili bkz. Karaman, Anahatlarıyla İslâm Hukuku, 3: 34-35; H. Yunus Apaydın, "İrade Beyanı", Türkiye Diyanet Vakfı İslâm Ansiklopedisi (Ankara: TDV Yayınları, 1993), 22: 387-388.

${ }^{106}$ Ebû Zehra, el-Ahvâlü'ş-şahsiyye, 91-92.

${ }^{107}$ Akseki, "İslâmiyet ve Teaddüd-i Zevcât", 276-277, 310, 312.

${ }^{108}$ Akseki, "İslâmiyet ve Teaddüd-i Zevcât", 313.

109 İslâm hukukunda çok eşliliğin sınırlandırılması ile ilgili görüşler için bkz. Mansurizâde Saîd, "Taaddüd-i Zevcât İslâmiyette Men Olunabilir", İslâm Mecmuası 1/8 (İstanbul 1330): 233-238; (Babanzâde) Ahmed Naim, "Taaddüd-i Zevcât İslâmiyet'te Men Olunabilir mi imiş?: Mansurizâde Saîd Beyefendi'ye", Sebilü'r-Reşad [Sırat-ı Müstakim]11/298 (15 Mayıs 1329/1330): 216-221; Kevserî, Makālât, 109-113, 203-214; Ebû Zehra, el-Ahvâlü'şşahsiyye, 13, 90-91; M. Sellâm Medkûr, Nazariyyetü'l-ibâha inde'l-usuliyyîn ve'l-fukâhâ, (Kahire: Dâru'n-Nehdati'l-Arabiyye, 1984), 353-354; Abdüsselam Muhammed eş-Şerif Âlim, Nazariyyetü's-siyâseti'ş-şer'iyye, (Bingazi: Camiatü Karyûnûs, 1996), 172-177; Beşir el-Mekkî Abdüllâvî, Sultatü veliyyi'l-emr fi takyîdi'l-mubâh, (Beyrut: Dâru Mektebeti'lMaârif, 2011), 482-501; Halil Cin, Eski Hukukumuzda Evlenme, (Ankara: Ankara Üniv. Hukuk Fak. Yayınları,1974), 300-302; Aydın, İslam-Osmanlı Aile Hukuku, 188, 215; Mehmet Erdoğan, İslam Hukukunda Ahkâmın Değişmesi, (İstanbul: MÜIFV Yayınları, 1990), 158.
} 
serbesti alanını) sınırlandırma hak ve yetkisi bulunmaktadır. ${ }^{110}$ Nitekim 1917 tarihli Osmanlı Hukuk-ı Aile Kararnamesi'nin esbâb-ı mûcibesinde (Gerekçeli Kararında): “Umûr-i câizede veliyyü'l-emr'in selâhiyeti kaidesi müsellemattandır/Mubah (câiz) olan bir konuda devlet başkanının tasarruf yetkisine sahip olması herkesin kabul ettiği bir kaidedir"111 denilmektedir.

Buna göre kamu otoritesi çok eşliliğin meşruiyet ve ruhsat şartlarının denetimi ve bu hakkın kullanımını hâkimin iznine bağlanması ile ilgili kanuni bir düzenleme yaptığında bu düzenleme șer'an ve kazaen bağlayıcı olmaktadır. ${ }^{112}$ Dolayısıyla böyle bir hukuki düzenlemenin yapılması halinde kamu otoritesinin, gerekli inceleme ve araştırmayı yaptıktan sonra, şartları uygun olan erkeklerin çok eşlilik yapmasına izin vermesi, olmayanlara ise izin vermemesi mümkündür. Nitekim günümüzde birçok İslâm ülkesi Aile Hukuku Kanunu da bu tür düzenlemelere yer vermiştir. ${ }^{113}$

\section{Sonuç}

İslâm hukuku, belirli şartların ve gerekçelerin bulunması halinde bireysel ve toplumsal maslahatların giderilmesi için çok eşlilik kurumunu kabul etmiştir. Dolayısıyla İslâm hukukunda çok eşlilik, bir emir veya zorunluluk değil, istisnâî olarak teşri kılınmış bir ruhsat hükmüdür.

İslâm hukukunda çok eşlilik, hukuken meşru (mubah) olmakla birlikte her erkeğin keyfine göre kullanabileceği mutlak bir hak da değildir. Nitekim ilgili naslar incelendiğinde İslâm hukukunda çok eşliliğin mubah/meşru olabilmesinin; "eşler arasında adaleti gözetmek" ve "eşlerin nafakasını temin etmeye güç yetirebilmek" olmak üzere iki temel şarta bağlandı̆̆

110 İslâm hukukunda kamu otoritesinin prensip olarak mubahı (hukukî serbest alanı) sınırlandırma hak ve yetkisi ile ilgili bkz. Seyyid Bey, Fıkıh Usulü, 104-155; Mansurizâde Saîd "Cevâzın Ahkâm-ı Şer'iyyeden Olmadığına Dâir", İslâm Mecmuası 1/10, (İstanbul 1330): 295-303; Mansurizâde Saîd, "Taaddüd-i Zevcât İslâmiyette Men Olunabilir", s. 233238; Medkûr, Nazariyyetü'l-ibâha, 317-369; Beşir el-Mekkî Abdüllâvî, Sultatü veliyyi'l-emr fi takyîdi'l-mubâh, (Beyrut: Dâru Mektebeti'l-Maârif, 2011). Konuyla ilgili ayrıca bkz. Mecelle, md. 1192, 1197, 1200, 1254; Osmanlı Hukuk-ı Aile Kararnamesi (Esbâb-ı Mûcibe Lâyihası/Nikâh-ı Mükreh), s. 90-91; Erdoğan, Ahkâmın Değişmesi, 157-158, 177-198; Köse, Hakkın Kötüye Kullanılması, s. 81-83; Ahmet Akgündüz, Eski Anayasa Hukukumuz ve İslâm Anayasası, (İstanbul: Timaş Yayınları, 1995), 21-26; Ahmet Akgündüz-Halil Cin, Türkİslâm Hukuk Tarihi, (İstanbul: Timaş Yayınları, 1990), 1: 191-196.

111 Bkz. Ansay, Eski Aile Hukukumuza Bir Nazar, (Ankara: İstiklal Matbaacilık ve Gazetecilik Kollektif Ortaklığı, 1952), 27; Osmanlı Hukuk-ı Aile Kararnamesi (Esbâb-ı Mûcibe Lâyihası/Nikâh-ı Mükreh), 90; Aydın, Aile Hukuku (Esbâb-ı Mûcibe Lâyihası/NikâhI Mükreh), 276.

112 İbn Âbidîn, Reddü'l-muhtâr, I, 178; Mecelle, md. 1801; Apaydın, Hukuk Usûlü, 321, 323. 113 Şelebî, Ahkâmü'l-üsre, 244-245; Sibâî, el-Mer'e beyne'l-fikhi ve'l-kânûn, 88-90; Attâr, Teaddüdü'z-zevcât, 271-291; Abdüsselam Muhammed eş-Şerif Âlim, Nazariyyetü'ssiyâseti'ş-şer'íyye, (Bingazi: Camiatü Karyûnûs, 1996), 172-177; Ali-Öğüt, "Çok Evlilik”, 8: 367; İsmail Yalçın, "Günümüz İslâm Aile Hukuku Kanunlarında Çok Eşlilik Üzerindeki Sınırlamalar”, Insan ve Toplum Bilimleri Araștırmaları Dergisi 6/3 (2017): 1707-1725. 
görülmektedir.

Buna göre İslâm hukukunda çok eşliliğin meşruiyeti, erkeğin eşleri arasında maddi adaleti sağlayabilecek bir irade ve karaktere sahip olması şartına bağlanmıștır. Dolayısıyla maddi adaleti sağlama konusunda yetersiz olan, bir başka ifade ile eşlerine haksızlık ve zulüm yapma potansiyeline sahip olan erkeklerin aynı anda birden fazla kadınla evlenmesi caiz değildir. Kur'an'da, "Ne kadar uğraşırsanız uğraşın, kadınlar arasında adaleti yerine getiremezsiniz" (en-Nisa, 4/129) şeklinde ifade edildiği üzere "eşler arasında adaletin gözetilmesi" şartı, Şâri'in maksadına ve maslahata uygun olarak çok eşlilik ruhsatını kullanmak isteyen erkekler için yerine getirilmesi gerçekten zor bir şarttır.

Çok eşlilik hakkının kullanılmasının meşru olmasının ikinci temel şartı ise, önceki ve yeni tüm eşlerinin nafakasını temin etme konusunda ekonomik güç ve imkâna sahip olmaktır. Dolayısıyla ikinci eşin nafakasını temin etmek için yeterli mali/maddi imkâna sahip olmayan bir erkeğin, mevcut karısının üzerine ikinci bir kadınla evlenmek istemesi başkasının yani, hem birinci karısının hem de ikinci karısının hakkına gereken önemi göstermemektir. $\mathrm{Bu}$ ise bir nevi zülümdür. Zülüm ve başkasının hakkını çiğnemek ise İslâm'da caiz değildir.

Diğer taraftan İslâm hukukçuları çok eşliliğin meşruiyeti ile ilgili bu temel şartların dışında, çok eşliliğe ruhsat veren bireysel ve toplumsal bazı gerekçeler üzerinde durmuşlardır. Dolayısıyla İslâm hukukunda belirli şarlar ve gerekçeler çerçevesinde meşru kılınan çok eşlilik hakkının istismar edilmemesi için bu şartlara ve gerekçelere riayet edilmesi gerekmektedir. Aksi halde çok eşlilik hakkı teşri kılınma maksadına aykırı olarak kullanılmış olacaktır ki bu da onun şer’an cevazını tartışmalı hale getirecektir. Böyle bir durumda ise kamu otoritesinin çok eşlilik hakkının kullanılmasını denetlemesi ve bu hakkın kullanılmasını bazı kayıtlara bağlaması söz konusu olabilecektir.

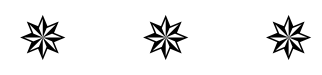

\section{KAYNAKÇA}

ABDÜLKADİR, Muhammed el-Arûsî. Ef'âlü'r-rasûl ve delâletühü ale'l-ahkâm. Cidde: Daru'l-müctemâ' li'n-neşr ve't-tevzî', 1991.

ABDÜLLÂVÎ, Beşir el-Mekkî. Sultatü veliyyi'l-emr fi takyîdi'l-mubâh. Beyrut: Dâru Mektebeti'l-Maârif, 2011.

AHMED NAİM, (Babanzâde). "Taaddüd-i Zevcât İslâmiyet'te Men Olunabilir mi imiş?: Mansurizâde Saîd Beyefendi'ye". Sebilü'r-Reşad [Sirat-ı Müstakim]11/298 (15 Mayıs 1329/1330): 216-221.

AKDAŞ, Hayrunnisa. II. Meşrutiyet Dönemi Fikir Akımlarının Taaddüd-i Zevcât 
Konusundaki Tartışmaları. Yüksek Lisans Tezi. Marmara Üniversitesi, 2016.

AKGÜNDÜZ, Ahmet. Eski Anayasa Hukukumuz ve İslâm Anayasası. İstanbul: Timaş Yayınları, 1995.

AKGÜNDÜZ, Ahmet-Cin, Halil. Türk-İslâm Hukuk Tarihi. 1-2. İstanbul: Timaş Yayınları, 1990.

AKSEKİ, Ahmed Hamdi. "İslamiyet ve Teaddüd-i Zevcât". Osmanlıdan Cumhuriyete İslam Düşüncesinde Arayışlar. 271-313. İstanbul: Rağbet Yayınları,1999.

AKYILDIZ, Ali. "Tanzimat". Türkiye Diyanet Vakfı İslâm Ansiklopedisi. 40: 110. Ankara: TDV Yayınları, 2011.

ALİ, Kevser Kâmil-Öğüt, Salim. "Çok Evlilik". Türkiye Diyanet Vakfi İslâm Ansiklopedisi. 8: 365-369. Ankara: TDV Yayınları, 1993.

ÂLIM, Abdüsselam Muhammed eş-Șerif. Nazariyyetü's-siyaseti'ş-şer'iyye: eddavâbit ve't-tatbîkât. Bingazi: Camiatü Karyûnûs, 1996.

ANSAY, Sabri Şakir. Eski Aile Hukukumuza Bir Nazar. Ankara: İstiklal Matbaacılık ve Gazetecilik Kollektif Ortaklığı, 1952.

ANSAY, Sabri Şakir. Hukuk Tarihinde İslâm Hukuku. İstanbul: Ajans Türk Matbaası, 1958.

APAYDIN, H. Yunus. "Nikâh Akdinin Mahiyeti ve İmam Nikâhı Uygulaması". Erciyes Ünv. Sosyal Bilimler Enst. Dergisi 9 (2000): 371-380.

APAYDIN, Yunus, "İrade Beyanı". Türkiye Diyanet Vakfı İslâm Ansiklopedisi 22: 387-388. Ankara: TDV Yayınları, 1993.

APAYDIN, H. Yunus. İslam Hukuk Usulü. Ankara: Bilay, 2017.

ARAS, Mehmet Özgü. “İslâm’a Göre Çok Evlilik”. Selçuk Üniversitesi İlahiyat Fakültesi Dergisi 24 (2007): 183-188.

ARSAL, Sadri Maksudi. Umumi Hukuk Tarihi. İstanbul: İstanbul Matbaacllık, 1948.

ATAR, Fahrettin. Fıkıh Usûlü. İstanbul: MÜİFV Yayınları, 1996.

ATTÂR, Abdünnâsır Tevfîk. Teaddüdü'z-zevcât mine’n -nevâhî'd-dîniyye ve'lictimâiyye ve'l-kānûniyye. Kahire: eș-Şirketü'l-Mısriyye li'tıbatati ve'nneşr, 1972.

AYDIN, M. Akif. İslâm-Osmanlı Aile Hukuku. İstanbul: MÜİFV Yayınları, 1985.

BARDAKOĞLU, Ali. "Haramlar ve Helaller". İlmihal (İslâm ve Toplum), 1-2. 29193. Ankara: Türkiye Diyanet Vakfı Yayınları, 2002.

BEŞER, Faruk. Güncel Meseleler Dini Çözümler. İstanbul: Nun Yayıncılık, 2008. 
İslâm Hukukunda Çok Eşliliği Meșru Kılan Şartlar ve Buna Ruhsat Veren Özel Durumlar

İstanbul: Bilmen Yayınları, 1985.

CARULLAH, Musa. Kur'an-ı Kerim Âyetlerinin Nurları Huzurunda Hatun. Yay. Haz: Mehmet Görmez. Ankara: Kitabiyat Yayınları, 1999.

CESSÂS, Ebu Bekir Ahmet b. Ali er-Râzî. Ahkāmül-Kur'an. 1-4. thk. Muhammed Sadık Kamhâvî, Beyrut: Dâru ihyâi't-türâsi'l-Arabî, 1985.

CiN, Halil. Eski Hukukumuzda Evlenme. Ankara: Ankara Üniversitesi Hukuk Fakültesi Yayınları, 1974.

ÇAĞRICI, Mustafa. "Adalet”. Türkiye Diyanet Vakfi İslâm Ansiklopedisi 1: 341343. Ankara: TDV Yayınları, 1988.

ÇAĞRICI, Mustafa. "İslâm Ahlakı". İlmihal (İslâm Ve Tolum), 1-2. 493-558. Ankara: Türkiye Diyanet Vakfı Yayınları, 2002.

DALGIN, Nihat. İslâm Hukukunda Boşama Yetkisi. Samsun: Etüt Yayınları, 1999.

DEBÛSÎ, Ebî Zeyd Ubeydullah b. Umer b. Îsâ. Takvîmü'l-edille fî usûli'l-fikh. thk. Şeyh Halil Muhyiddin el-Meys. Beyrut: Dâru'l-kütübi'l-ilmiyye, 2007.

DEMIRCAN, Adnan. "Câhiliye ve Hz. Peygamber Döneminde Çok Kadınla Evlilik". İstem 1/2 (2003): 9-32.

DEMIRCAN, Ali Rıza. "Çok Eşlilik". Hz. Peygamber ve Aile Hayatı. Yay. Haz. İsmail Lütfi Çakan. 248-251. İstanbul: İlmi Neşriyat, ty.

DEMIRCAN, Ali Rıza, "Ailede Cinsel Hayat". Aile ve Eğitim-Tartışmalı İlmi Toplantı- (24-25 Nisan 2010). 133-153. İstanbul: 2010.

DURMUŞ, Abdullah. “Ahmed Hamdi Akseki'nin Birden Fazla Evlilik (Çok eşlilik) Konusundaki Yaklaşımı". İstanbul Üniversitesi Illahiyat Fakültesi Dergisi 32 (2015): 251-276.

Ebû CEYB, Sa'dî. Mevsûatü'l-icma' fi'l-fikhi'l-islâmî. 1-2. Dımeşk: Dâru'l-fikr, 1984.

Ebû ZEHRA, Muhammed. el-Ahvâlü'ş-şahsiyye, Kâhire: Dâru'l-fikri'i-Arabî, 1957.

Ebû ZEHRA, Muhammed. el-Muhâdarât fì akdi'z-zevâc ve eserih. Kahire: Daru'l-fikri'l-arabî, 1971.

Ebû ZEHRA, Muhammed. Tanzîmü'l-üsra ve tanzîmü'n-nesl. Kahire: Daru'lfikri'l-arabî, 1976.

Ebû ZEHRA, Muhammed. el-Mevsûâtüll-fikhiyye. "Nikâh". Vizâratü'l-evkâf ve'ş-şuûni'd-dîniyye. 41: 205-355. Kuveyt: 2002.

ELMALILI, Muhammed Hamdi Yazır. Hak Dini Kur'ân Dili. 1-10. İstanbul: Eser Neşriyat, 1979.

ERBAY, Celal. "Nafaka”. Türkiye Diyanet Vakfı İslâm Ansiklopedisi. 32: 282- 
285. Ankara: TDV Yayınları, 2006.

ERDOĞAN, Mehmet. İslâm Hukukunda Ahkâmın Değişmesi. İstanbul: MÜIFV Yayınları, 1990.

ERDOĞAN, Mehmet. Flkıh ve Hukuk Terimleri Sözlügü. İstanbul: Rağbet Yayınları, 1998.

FATMA ALIYE-Mahmud Esad. Çok Eşlilik (Teaddüd-i Zevcât). Haz: Firdevs Canbaz. Ankara: Hece Yayınları, 2007.

HAMIDULLAH, Muhammed. "Müslümanlarda Hukuk Felsefesi". trc. İ. Kâfi Dönmez. İslâm Medeniyeti 4/4 (1980): 19-34.

HEYET. Hz. Peygamber ve Aile Hayatı, Yay. Haz. İsmail Lütfi Çakan. İstanbul: İlmi Neşriyet (ISAV), 1989.

İbn ÂŞÛR, Muhammed Tahir. et-Tahrîr ve't-tenvîr. 1-30. Tunus: Dâru'Tûnisiyye, 1984.

İbn KAYYİM el-Cevziyye. Zâdü'l-meâd fî hedyi hayri'i-lbâd, thk. Şuayb elArnavut-Abdülkadir el-Arnavut. 1-4. Beyrut: Müessesetü'r-risâle, 1994.

İbn KUDÂME, Muvaffaküddin Abdullah b. Ahmed el-Makdisî. el-Muğnî. 1-15. thk. Abdullah b. Abdülmuhsin et-Türkî-Abdülfettah Muhammed elHulüv. Riyad: Dâru Âlemi'l-kütüb, 1997.

İbn RÜŞD. Bidâyetüll-müctehid ve nihâyetü'l-muktesid. 1-2. Beyrut/Kahire: Dâru'l-ceyl-Mektebetü'l-külliyeti'l-ezheriyye, 2004.

İbnü'l-ARABÎ. Kadı Ebu Bekir. Ahkâmü'l-Kur'ân. 1-4. thk./tlk. Muhammed Abdülkadir Ata, Beyrut: Dâru'kütübi'l-ilmiyye, 2003.

İNCEGÜL, Sümeyye. Tanzimat'tan Günümüze Çok Evlilik Tartışmaları. Yüksek Lisans Tezi. Erciyes Üniversitesi, 2008.

KAL'ACÎ, Muhammed Ravvâs-Kuneybî, Hamid Sâdık. Mu'cemü lüğati'lfukahâ. Beyrut: Daru'n-nefâis, 1985.

KARAMAN, Hayreddin. "Adalet (Fıkıh)". Türkiye Diyanet Vakfı İslâm Ansiklopedisi. 1: 343-344. Ankara: TDV Yayınları, 1988.

KANLIDERE, Ahmet. "Musa Carullah". Türkiye Diyanet Vakfı İslâm Ansiklopedisi. 26: 214-216. Ankara: TDV Yayınları, 2002.

KARAMAN, Hayreddin. Ana Hatlariyla İslâm Hukuku. 1-3. İstanbul: Ensar Neşriyat, 2011.

KARAMAN, Hayreddin. İslâm'da Kadın ve Aile. İstanbul: Ensar Neşriyat, 1994.

KEVSERÎ, Muhammed Zâhid. Makālâtü'l-Kevserî. Kahire: el-Mektebetü'ttevfîklyye, ty.

KÖSE, Saffet. İslâm Hukukunda Hakkın Kötüye Kullanılması. İstanbul: MÜíFAV Yayınları, 1997. 
İslâm Hukukunda Çok Eşliliği Meșru Kılan Şartlar ve Buna Ruhsat Veren Özel Durumlar

KÖSE, Saffet. "Aile Hukuku”. İslâm Hukuku El Kitabı. edt. Talip Türcan. 437533. Ankara: Grafiker Yayınları, 2012.

KURTUBÎ, Ebû Abdillah Muhammed b. Ahmed el-Ensârî. el-Câmi' li ahkâmi'lKur'ân. 1-24. thk. Abdullah b. Abdulmuhsin et-Türkî. Beyrut: Müessesetü'r-risâle, 2006.

MANSURIZÂDE, Saîd. “Taaddüd-i Zevcât İslâmiyette Men Olunabilir”. İslâm Mecmuası 1/8 (İstanbul 1330): 233-238.

MANSURIZÂDE, Saîd. "Teaddüd-i Zevcât Münâsebetiyle (Efkâr-1 Umûmiyyeye)". İslâm Mecmuası 1/11 (İstanbul 1330): 329-330.

MANSURIZÂDE, Saîd. “Cevâzın Ahkâm-ı Şer'iyyeden Olmadığına Dâir”. İslâm Mecmuası 1/10 (İstanbul 1330): 295-303.

MEDKÛR, M. Sellâm. Nazariyyetu'l-ibâha inde'l-usuliyyîn ve'l-fukâhâ. Kahire: Dâru'n-Nehdati'l-Arabiyye, 1984.

MERGÎNÂNî, Ali b. Ebî Bekr. el-Hidâye şerhu Bidâyeti'l-mübtedî. 1-4. İstanbul: Kahraman Yayınları 1986.

ORTAYLI, İlber. Osmanlı Toplumunda Aile. İstanbul: Timaş Yayınları, 2016.

Osmanlı Hukuk-ı Aile Kararnamesi. Yay. Haz. Orhan Çeker, Konya: Mehir Vakfı Yayınları, 2012.

ÖZTÜRK, Mustafa. Cahiliyeden İslâmiyet'e Kadın. Ankara: Ankara Okulu Yayınları, 2012.

REŞiD RIZA, Muhammed. Tefsîrü'l-Menâr/Tefsîru'l-Kur'ân'il-Hakîm. 1-12. Mısır: Matbaatü'l-Menâr, 1328 h.

REŞiD Rıza, Muhammed. Hukûku'n-nisâ fi'l-İslâm. Beyrut: el-Mektebetü'lislâmî, 1984.

SEYYID BEY, Muhammed. Fıkıh Usulü (Girişs). Yay. Haz: Hasan Karayiğit. İstanbul: Düşün Yayınları, 2010.

Si̇BÂÎ, Mustafa. el-Mer'e beyne'l-fikhi ve'l-kānûn. Beyrut: el-Mektebetü'lislâmî, 1999.

ŞABAN, Zekiyyüddin. İslâm Hukuk İlminin Esasları (Usûlü'l-fıkıh). trc. İbrahim Kâfi Dönmez. Ankara: Diyanet Vakfı Yayınları, 2015.

ŞELEBÎ, Muhammed Mustafa. Ahkāmü'l-üsre fi'l-İslâm. Beyrut: Dârü'nNehdati'l-Arabiyye, 1977.

ŞiRBîNî, Şemsüddin b. Muhammed b. el-Hatîb. Muğni'l-muhtâc. 1-4. Beyrut: Dâru'l-ma'rife, 1997.

TOPALOĞLU, Bekir. İslâmda Kadın. İstanbul: Yağmur Yayınları, 1990.

ULAŞ, Semra. “İslâm'da Çok Kadınla Evlilik". İslâmî Araştırmalar 4/1 (1992): 52-63. 
YALÇIN, İsmail. "Günümüz İslâm Aile Hukuku Kanunlarında Çok Eşlilik Üzerindeki Sinırlamalar". Insan ve Toplum Bilimleri Araştırmaları Dergisi 6/3 (2017): 1707-1725.

YILDIRIM, Mustafa. "Nisa Suresi 3. Ayet Bağlamında Çok Eşlilik Meselesi", Dinlerde Nikâh Milletlerarası Tartışmalı Illmi Toplantı (İzmir 06-08 Nisan 2012), 533-546. İstanbul: 2012.

ZERKĀ, Mustafa Ahmed. el-Medhalül-fikhiyyü'l-âmm/el-Fıkhu'l-İslâmî fi sevbihi'l-cedîd. 1-3. Dimeşk: Dâru'l-Fikr, 1968.

ZEYDAN, Abdülkerim. el-Vecîz fî usûli'l-fıkh. Beyrut: Müessesetü'r-Risâle, 2011.

ZEYDAN, Abdülkerim. el-Mufassal fî ahkāmi'l-mer'e ve'l-beyti'l-müslim fi'şşerîati'l-islâmiyye. 1-11. Beyrut: Müessesetü'r-risâle, 1993.

ZÜHAYLÎ,, Vehbe. el-Fıkhü'l-islâmî ve edilletühû. 1-8. Dımeşk: Dâru'l-fikr, 1989.

竢的 


\title{
CONDITIONS THAT MAKE POLYGAMY LEGITIMATE AND SPECIAL CONDITIONS THAT ALLOW POLYGAMY IN ISLAMIC LAW
}

\author{
(1) İbrahim YILMAZa
}

\section{Extended Abstract}

Polygamy, the marriage of a man with more than one woman at the same time is a known and practiced institution in human history. Islamic law has accepted the institution of polygamy if it fulfills certain conditions and reasons as a substitute provision and limited the number to four. Thus, relevant verses in the Qur'an (al-Nisa, 4/3, 129) and the Prophet's own practice (al-Ahzab, 33/50, 51, 59, al-Tahrim, $66 / 3-5$ ) shows that it is legitimate for a man to marry more than one woman (up to four) at the same time in Islamic law.

Although polygamy is legally legitimate (mubah) in Islamic law it is not an absolute right that every man can arbitrarily use. Thus in Islamic law, the legitimacy of polygamy has been attributed to the presence of two basic conditions: the observance of justice and sustenance.

On the other hand, there may be some exceptional special circumstances permitting polygamy in Islamic law. For example, in the society, when the female population is too much, or because the woman is not always able to fulfill her family duties due to her cureless illness, polygamy is permitted in Islamic law.

As it can be understood from the explanations above, polygamy in Islamic law is not a mandatory provision that should be applied by every man with the capacity to marry. On the contrary, it is an exceptional provision that is justified if there are ertain conditions and justifications.

According to this; in Islamic law, polygamy is a moral and legal institution

\footnotetext{
a Assoc. Prof., Nevşehir Hacl Bektaş University Theology Faculty, ibrh.yilmaz@hotmail.com
} 
that is made up of mutual consent based on individual and social conditions and needs. Therefore, men do not have to marry a second woman on their current wives, women also have the right to say no to marry a married man as a second wife.

When the conditions and rationales in the relevant verses and doctrine are evaluated together, it can be said that in order to be able to legitimize the polygamy in Islamic law, there must be three basic conditions:

1. Compliance with justice among spouses,

2. To have sufficient financial power to provide the support of spouses,

3. Individual or social need or necessity.

Therefore, in order to prevent the exploitation of polygamy, which is justified under certain conditions and justifications in Islamic law, the abovementioned conditions must be fulfilled. Otherwise, it is possible that polygamy, which is legitimized by Islam for certain conditions and justifications, can cause some problems, unrest and injustice for the individual, family and society. Therefore, in the framework of certain conditions and justifications, polygamy accepted by Islamic law is a moral and legal institution aimed at the elimination of individual and social arbitration.

After these explanations, it is possible to say about the legitimacy of polygamy in Islamic law;

1. Polygamy is an exceptional provision that is justified if there are certain conditions and reasons.

2. Polygamy is an application depending on the existence of individual or social arbitration.

3. Polygamy depends on the existence of the requirement of justice among spouses.

4. Polygamy depends on the condition of providing sustenance of spouses.

5. Polygamy has been justified in order to get rid of bigger damages and evils.

6. Polygamy is not legitimate in the case of damages and injustices for spouses.

On the other hand, Islamic jurists say that the marriage agreement with a second woman on the current spouse, regardless of the conditions of justice and alimony, is valid. In other words, although the provision of justice and 
the provision of alimony for the legitimacy of polygamy is stipulated, these two conditions are not the conditions of validity of the marriage contract. Therefore, the second marriage made without fulfilling these two conditions is valid. But the husband is a sinner because he does not provide justice among his wives. He will render an account of this injustice to God.

Although the legitimacy of polygamy in Islamic law depends on the existence of certain conditions and special circumstances, it is a known fact that it is not observed in practice. Hence, in practice, the right to polygamy is a subject of abuse. Therefore, in the historical process, the limitation of polygamy by the public authority has come to the fore. Today, among the Islamic jurists, the case that the public authority control and limitation of polygamy is continued to be discussed.

In summary, the verses on the subject show that polygamy is legitimate (mubah) as a license provision in Islamic law. However, the exercise of this right depends on the existence of conditions such as taking care of the justice of spouses and ensuring the support of spouses. In addition, monogamy is essential in Islamic family law. In case individual or social specific circumstances (conditions) are fulfilled, polygamy is allowed. On the other hand, in Islamic law, it is also possible to limit the polygamy by public authority.

In this article, the legitimacy of polygamy and some special situations that allow the polygamy in Islamic family law will be focused on.

Keywords: Islamic Law, Polygamy, Rukhșa, Special Conditions.

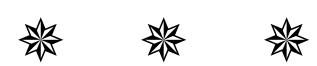

